\title{
2,3-Diaminopropanols Obtained from D-Serine as Intermediates in the Synthesis of Protected 2,3-L-Diaminopropanoic Acid (L-Dap) Methyl Esters
}

\author{
Andrea Temperini ${ }^{1}$, Donatella Aiello ${ }^{2} \mathbb{1}$, Fabio Mazzotti ${ }^{2}$, \\ Constantinos M. Athanassopoulos ${ }^{3}(\mathbb{D})$, Pierantonio De Luca ${ }^{4}$ (D) and Carlo Siciliano ${ }^{5, *(D)}$ \\ 1 Dipartimento di Scienze Farmaceutiche, Università di Perugia, Via del Liceo 1, 06123 Perugia, Italy; \\ andrea.temperini@unipg.it \\ 2 Dipartimento di Chimica e Tecnologie Chimiche (CTC), Via Ponte P. Bucci, Cubo 12D, Università della \\ Calabria, I-87036 Arcavacata di Rende (CS), Italy; donatella.aiello@unical.it (D.A.); \\ fabio.mazzotti@unical.it (F.M.) \\ 3 Department of Chemistry, University of Patras, GR-26504 Patras, Greece; kath@chemistry.upatras.gr \\ 4 Dipartimento di Ingegneria Meccanica, Energetica e Gestionale, Università della Calabria, I-87036 \\ Arcavacata di Rende (CS), Italy; pierantonio.deluca@unical.it \\ 5 Dipartimento di Farmacia e Scienze della Salute e della Nutrizione, Edificio Polifunzionale, Università della \\ Calabria, I-87036 Arcavacata di Rende (CS), Italy \\ * Correspondence: carlo.siciliano@unical.it; Tel.: +39-0984-493192
}

Academic Editors: M. Graça P. M. S. Neves and Gianfranco Favi Received: 22 February 2020; Accepted: 12 March 2020; Published: 13 March 2020

\begin{abstract}
A synthetic strategy for the preparation of two orthogonally protected methyl esters of the non-proteinogenic amino acid 2,3-L-diaminopropanoic acid (L-Dap) was developed. In these structures, the base-labile protecting group 9-fluorenylmethyloxycarbonyl (Fmoc) was paired to the $p$-toluensulfonyl (tosyl, Ts) or acid-labile tert-butyloxycarbonyl (Boc) moieties. The synthetic approach to protected L-Dap methyl esters uses appropriately masked 2,3-diaminopropanols, which are obtained via reductive amination of an aldehyde prepared from the commercial amino acid $N^{\alpha}$-Fmoc-O-tert-butyl-D-serine, used as the starting material. Reductive amination is carried out with primary amines and sulfonamides, and the process is assisted by the Lewis acid $\operatorname{Ti}\left(\mathrm{O}^{i} \mathrm{Pr}\right)_{4}$. The required carboxyl group is installed by oxidizing the alcoholic function of 2,3-diaminopropanols bearing the tosyl or benzyl protecting group on the $3-\mathrm{NH}_{2}$ site. The procedure can easily be applied using the crude product obtained after each step, minimizing the need for chromatographic purifications. Chirality of the carbon atom of the starting D-serine template is preserved throughout all synthetic steps.
\end{abstract}

Keywords: 2,3-L-diaminopropanoic acid; L-Dap; basic amino acids; serine; reductive amination; orthogonal protecting groups; 1,3,5-trichloro-2,4,6-triazinetrione; trichloroisocyanuric acid (TCCA); (2,2,6,6-tetramethylpiperidi-1-yl)oxyl (TEMPO); $N$-methylation

\section{Introduction}

\subsection{The Role of $\mathrm{L}$-Dap in Natural and Synthetic Compounds}

2,3-L-Diaminopropanoic acid (L-Dap) is a non-proteinogenic amino acid produced by numerous plants and bacteria [1]. It is the main structural motif of albizziine, a natural non-proteinaceous free amino acid which is ubiquitously present in higher plants and in seeds [2]. The known preparative methods for the total synthesis of albizziine employs protected derivatives of L-Dap as the starting materials [3]. Bleomycins (BLMs) are structurally related glycopeptide-derived 
antitumor antibiotics, and they display a L-Dap amide common scaffold as the chain N-terminus [4-8]. L-Dap is also one of the most frequently found amino acids inserted in bioactive peptides, such as cyclotheonamide $\mathrm{B}$, phleomycin, paenibacterin derivatives, lavendomycin, gastrin-releasing peptide receptor-specific scaffolds, capreomycin, various peptide-based antibacterials, and peptidomimetics, such as vitronectin [9-16]. Protected L-Dap derivatives were proposed as powerful inhibitors of the formation of advanced glycosylation end-products (AGEs), which are implicated in the development of diabetes mellitus and neurodegenerative Alzheimer's and Parkinson's diseases [17]. Advanced lipid peroxidation end-product (ALE) formation can also be modulated by the same L-Dap derivatives used to control AGE cascades, against the endogenous peroxidation of polyunsaturated fatty acids [17]. Matrix metalloproteases, containing L-Dap as the terminal carboxylate amino acid unit, were synthesized and biologically tested for their roles in the degradation and remodeling of connective tissues [18]. L-Dap is contained in staphyloferrin B, as well as in a series of synthetic and natural siderophores $[19,20]$. Appropriately protected L-Dap subunits were used as building blocks in the solid-phase synthesis of chelating peptide conjugates having therapeutic and diagnostic applications in tumor diseases [21]. Dismutation of superoxide species can be controlled by metal complexes of L-Dap branched peptides with divalent cations [22,23]. L-Dap dipeptides were used as reference structures to investigate the ionizability of side-chain primary amino functions in amino acids [24], and the substitution of aspartic units by L-Dap was adopted in the synthetic preparation of glycoproteins [25]. L-Dap acts as crosslinker in graphene sponges of clinical importance for hemostasis control [26], and it is a component of biosynthetic model compounds employed in studies aiming to define acyl-enzyme activities and foldings $[27,28]$. L-Dap-based peptide dendrimers catalyze asymmetric processes in organic synthesis $[29,30]$. Furthermore, L-Dap-enriched peptide backbones were obtained for gene silencing scopes [31], and synthetic orthogonally $N^{\alpha}, N^{\beta}$-diprotected L-Dap-based nucleoamino acids were investigated for the assembly of cationic nucleopeptides in biomedical applications [32]. Recently, the identification of L-Dap in the Murchison chondritic meteorite [33] suggested the possible role of this non-proteinogenic amino acid as a selective molecular target to investigate prebiotic polycondensation processes of importance in establishing the appearance of life on Earth [34].

\subsection{Synthetic Routes to L-Dap}

The last decade was characterized by the disclosure of a wide range of synthetic routes to L-Dap and its analogues. Much effort was spent searching for convenient methods which could employ simple molecular scaffolds [35]. Natural amino acids were proposed as convenient starting materials; however, the use of serine was seldom investigated [36-39]. A combination of the classical series of acidand base-labile masking groups used in the solution and solid-phase peptide synthesis was generally found advantageous. The installation of two or more amino functions in natural carbon backbones and their heterocycle analogues might present additional difficulty [40]. Another critical step is the preservation of the absolute configuration of chiral carbon atoms when molecules from the natural chiral pool might be used as enantiomerically pure starting materials. Differently $N^{\alpha}, N^{\beta}$-diprotected L-Dap, as well as its mono- and di-alkylated derivatives, was obtained through a plethora of synthetic approaches [41-52]. In general, the published methods are characterized by variable overall yields in L-Dap, and they are notable for needing several steps of chromatography and for the problematic stereochemical control of reactions.

\section{Scope of the Work}

The scope of the present work was an investigation of a preparative route to appropriately protected L-Dap methyl esters, which may further be employed in branching, alkylation, cyclization, cross-linking, and solid-phase peptide synthesis. More specifically, we were attracted by the design of an advantageous synthetic procedure that might include (i) the easy replacement of protections placed on the amino functions of L-Dap, (ii) the methylation of the carboxyl function to obtain L-Dap methyl 
esters, and (iii) the possible use of appropriate masking groups which could enable a chemoselective $N^{\beta}$-methylation, in order to prepare suitable scaffolds for the elaboration of alkylated L-Dap derivatives.

In particular, our synthetic plan was chalked out starting from optically pure protected D-serine. The key synthetic step of the procedure was the $\mathrm{Ti}\left(\mathrm{O}^{\mathrm{i}} \mathrm{Pr}\right)_{4}$-assisted reductive amination [53-55] of a protected D-serine aldehyde derivative to give a series of protected 2,3-diaminopropanols, which were oxidized under mild conditions [56,57]. It is worth noting that D-serine was used to obtain the correct L-Dap stereochemistry.

\section{Results and Discussion}

\subsection{Retrosynthetic Analysis}

Scheme 1 shows the retrosynthetic analysis for obtaining $N^{\alpha}, N^{\beta}$-diprotected L-Dap methyl esters. Enantiomerically pure Fmoc-O-tert-butyl-D-serine (1), commercially available at low cost, was selected as the ideal precursor of the targeted compounds.

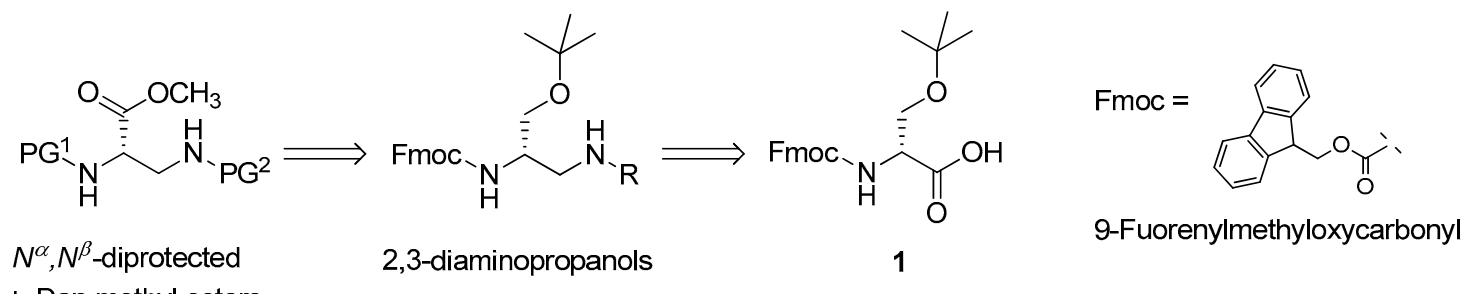

L-Dap methyl esters

Scheme 1. The retrosynthetic analysis for the preparation of orthogonally $N^{\alpha}{ }_{,} N^{\beta}$-diprotected 2,3-L-diaminopropanoic acid (L-Dap) methyl esters ( $\mathrm{PG}^{1}$ and $\mathrm{PG}^{2}$ are orthogonal groups).

It was thought feasible to realize the desired 2,3-diamino framework via the synthesis of suitable intermediates having a 2,3-diaminopropanol scaffold, prepared via reductive amination of a D-serine aldehyde derivative with different primary amines and arylsulfonamides, bearing protecting groups compatible with the conditions of the solution and solid-phase peptide chemistry. The mild oxidation of alcohol group of the amine-protected 2,3-diaminopropanols could generate the carboxylic group required to complete the 2,3-diamino acid backbone. Finally, the carboxyl function can easily be methylated to afford the desired fully protected L-Dap methyl esters. The plan was designed in order to protect the 2- $\mathrm{NH}_{2}$ group of the methyl esters with the base-labile Fmoc group $\left(\mathrm{PG}^{1}\right)$. In that structure, the 3- $\mathrm{NH}_{2}$ amino function could orthogonally be protected to give a tosyl derivative, or one with an acid-labile Boc group $\left(\mathrm{PG}^{2}\right)$. In the 2,3-diamminopropanol intermediates, the simultaneous presence of a benzyl moiety and an orthogonal Fmoc protection on the 3- and 2- $\mathrm{NH}_{2}$ functions, respectively, could also support the facile interconversion of the pair of amino protections, enabling the installation of Boc $\left(\mathrm{PG}^{1}\right)$ and Fmoc $\left(\mathrm{PG}^{2}\right)$ groups at the 2- and 3-positions of the final L-Dap methyl ester structures.

\subsection{Synthesis of the 2,3-Diaminopropanols}

Scheme 2 displays our synthetic route to the Fmoc-protected 2,3-diaminopropanol intermediates 4-10. These compounds were obtained via reductive amination of 3 with amines and sulfonamides. The protected amino acid 1 reacted with $\mathrm{N}, \mathrm{O}$-dimethylhydroxylamine hydrochloride [58] to give the Weinreb-Nahm amide 2, which was recovered in a 94\% yield, without need for chromatographic purification. Reduction of 2 by $\mathrm{LiAlH}_{4}$ afforded the corresponding $\alpha$-amino aldehyde 3, which was obtained in a 92\% yield, avoiding chromatography. The structures of compounds 2 and 3 were confirmed by ${ }^{1} \mathrm{H}$ - and ${ }^{13} \mathrm{C}-\mathrm{NMR}$ spectroscopy. Compound 3 was then subjected to the reductive amination with a series of primary amines and sulfonamides having different structural characteristics. Benzylamine was chosen as an ideal model to check the reaction performance. The process was assisted by the Lewis acid $\mathrm{Ti}\left(\mathrm{O}^{\mathrm{i}} \mathrm{Pr}\right)_{4}$, in the presence of sodium cyanoborohydride, a reducing agent which is widely employed in metal-assisted reactions of amino acids and their derivatives $[59,60]$. 
Primary amines result in the removal of the base-labile $N$-masking Fmoc group; however, the use of a Lewis acid prevents this practical inconvenient [61]. Compound 3 reacted smoothly with benzylamine, in the presence of the titanium(IV) species and the hydride donor, to afford 4 in excellent yields (92\%), after chromatography. Thin-layer chromatography (TLC) analysis, as well as the ${ }^{1} \mathrm{H}-\mathrm{NMR}$ spectrum of the crude reaction material, highlighted the absence of unwanted by-products generated through the removal of the base-labile Fmoc protecting group.

Table 1. Reductive amination of 3: synthesis of the 2,3-diaminopropanol intermediates.

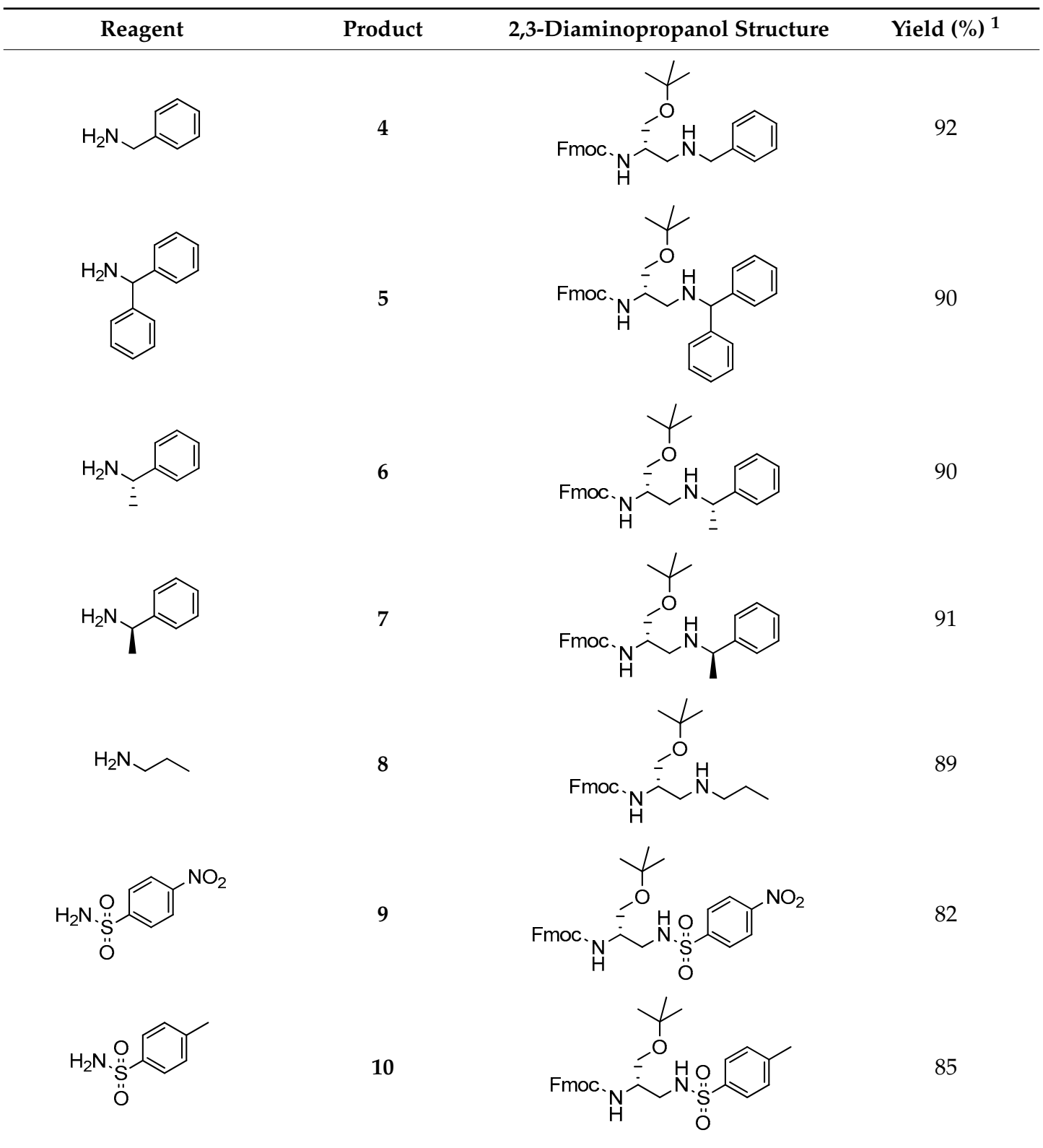

${ }^{1}$ Yields in final products obtained after chromatography. 


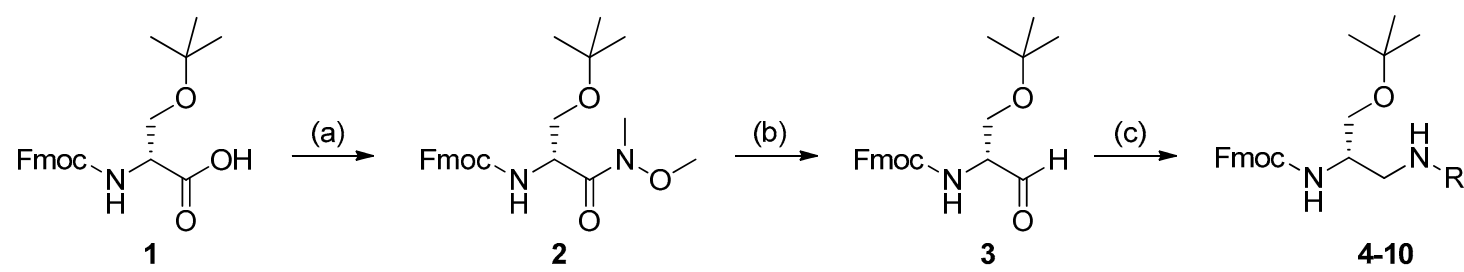

Scheme 2. Synthesis of Fmoc-2,3-diaminopropanols 4-10. Experimental conditions: preparation of the Weinreb-Nahm amide 2, (a) 1-hydroxybenzotriazole (HOBt) monohydrate/ $N, N^{\prime}$-diisopropylcarbodiimide (DIC)/1-(3-dimethylaminopropyl)-3-ethylcarbodiimide hydrochloride (EDC), $2 \mathrm{~h}$, room temperature (r.t.); then, $\mathrm{N}, \mathrm{O}$-dimethylhydroxylamine hydrochloride/DIEA/DCM, overnight, r.t. (94\% yield); preparation of the Garner-like aldehyde 3, (b) $\mathrm{LiAlH}_{4} / \mathrm{THF}, 12 \mathrm{~min}$, r.t. (92\% yield); reductive amination, (c) amine or arylsulfonamide/Ti( $\left(\mathrm{O}^{\mathrm{i}} \mathrm{Pr}\right)_{4} / \mathrm{EtOH}, 10 \mathrm{~min}$, r.t., then $\mathrm{NaBH}_{3} \mathrm{CN}$, overnight, r.t. $(82 \%-92 \%$, Table 1$)$.

The molecular structure of 4 was confirmed by one- and two-dimensional (1D and 2D) NMR spectroscopy. In particular, the $1 \mathrm{D}^{1} \mathrm{H}$ - and ${ }^{13} \mathrm{C}-\mathrm{NMR}$ spectral plots displayed the correct number, multiplicity, and integral values of all resonances assignable to the expected structure of 4 . The contour plot of the 2D homonuclear proton TOCSY spectrum of the benzyl derivative 4 did not show signal overlap, facilitating the recognition of a set of cross-peaks at $5.52 \mathrm{ppm}$, in the regions between 3.90 and $3.40 \mathrm{ppm}$, and between 2.60 and $2.90 \mathrm{ppm}$, which were generated by the resonances of all correlated protons along the molecular backbone of 4 (Figure 1). Two-dimensional spectroscopy unequivocally proved the successful installation of the second amino function in substitution of the hydroxyl group of the starting D-serine backbone. These results highlighted that the reductive amination process can be a useful strategy for the realization of orthogonally protected 2,3-diaminopropanols.

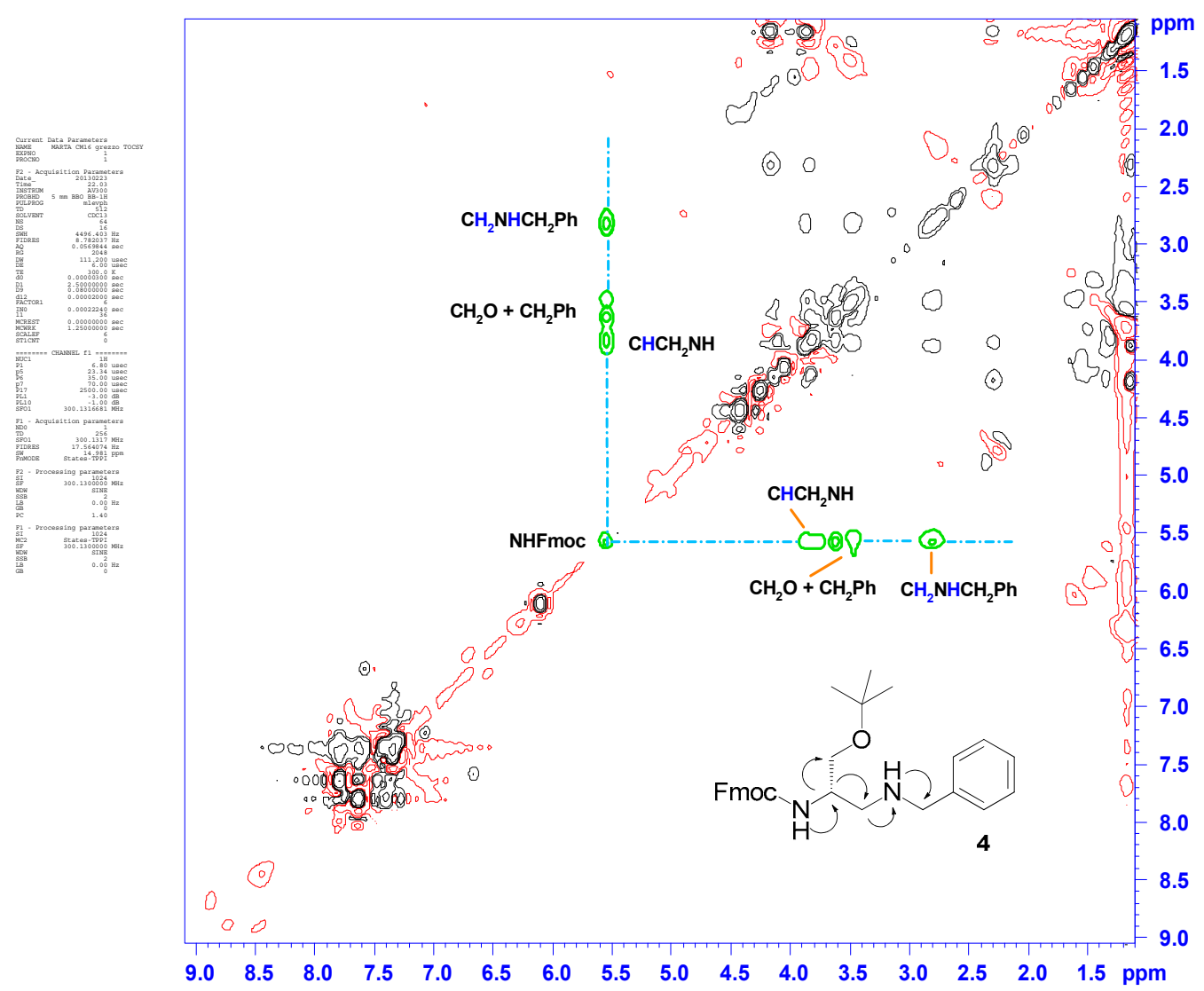

Figure 1. Contour plot of the two-dimensional (2D) homonuclear ${ }^{1} \mathrm{H},{ }^{1} \mathrm{H}$-TOCSY spectrum recorded for compound 4 . 
The more sterically demanding diphenylmethylamine (benzhydrylamine) was a probe for observing the possible steric effects exerted by the nucleophile, as well as to prepare a 2,3-diaminopropanol scaffold containing the acid-labile benzhydryl masking group, which is orthogonal to the Fmoc protection [62]. Treatment of 3 with benzhydrylamine afforded the corresponding protected 2,3-diaminopropanol 5, which was obtained in a 90\% yield after chromatography. Results highlighted that the nucleophile size did not modify yields and reaction times. The proton NMR spectrum of 5 showed signal duplication, line broadening, and overlapping. Spectral data suggested the possible presence in solution of two main set of conformers in a 75:25 ratio, at the temperature fixed for NMR experiments. Coexistence of the two conformers is likely due to the slow rotation (on the NMR time-scale) around the amide bond of the carbamate residue. In carbamates, the two conformers syn and anti undergo dynamic exchange, with a general predominance of the anti isomer conformation with respect to its syn counterpart due to steric and electrostatic effects that can change the dipole moment and bond angles [63,64]. Solvent, temperature, and concentration can affect the free energy difference between the syn and anti conformers [65], and intra- and intermolecular hydrogen bonding may also perturb the syn/anti equilibrium [66]. In the case of compound 5, the minor conformer was observable since it could be stabilized by the size and electronic effects of the benzhydryl group, as well as by the NMR solvent that could remarkably influence transition state energies and the rotational barrier in the syn/anti conformer exchange [67].

Alkylation of the amino functions is one of the most interesting modifications of L-Dap, and methylation of the 3- $\mathrm{NH}_{2}$ group is a structural feature displayed by many biologically active compounds [68,69]. Reductive amination of 3 with $n$-propylamine (Scheme 1, Table 1) gave 8 in an $89 \%$ yield after chromatography. The reaction represented a short route to the direct alkylation of the 3- $\mathrm{NH}_{2}$ function of the 2,3-diaminopropanol scaffold, and the $n$-propyl derivative 8 was considered to be a possible precursor in the synthesis of alkylated L-Dap structures.

\subsection{Analysis of Racemization}

Chiral $\alpha$-amino aldehydes show the tendency to racemize under acidic or basic conditions, as well as during chromatographic purification over silica gel [70]. In order to check whether the chiral carbon atom configuration of the starting $\mathrm{D}$-serine is preserved during the reductive amination process, the $\alpha$-amino aldehyde 3 was reacted with the enantiomerically pure $(S)$ and $(R)$ isomers of 1-methylphenylamine. Reactions gave the corresponding diastereomeric 2,3-diaminopropanols 6 and 7 (Scheme 2, Table 1), which were obtained in a 90\% and 91\% yield, respectively, after chromatography. Both pure compounds 6 and 7 exhibited the expected molecular structure, as established by ${ }^{1} \mathrm{H}-$ and ${ }^{13} \mathrm{C}-\mathrm{NMR}$ analysis and MS experiments. The NMR analysis was extended to the respective crude materials, as obtained from the reaction work-up, avoiding further purification steps. In this case, each NMR spectrum displayed signals which were diagnostically correlated to the proton and carbon resonances of a single diastereomer, with no evidence for signals attributable to other diastereomers, at least under the sensitivity limits of the spectrometric technique. Spectral data indicated that the $\mathrm{Ti}(\mathrm{IV})$-assisted process of the imine intermediates was stereospecific [71]. Moreover, the absence of detectable resonance signals due to diastereomeric mixtures in each crude sample suggested that the reductive amination proceeded with no change of the configuration of the chiral carbon atom of 3 , consequently preserving the stereochemistry of the starting amino acid $\mathbf{1}$. The absence of racemization was definitively confirmed by reverse-phase (RP) U-HPLC/MS analysis. Chromatograms recorded for separate injections of crude 6 and 7 showed a single elution peak for each compound (Figure 2). 

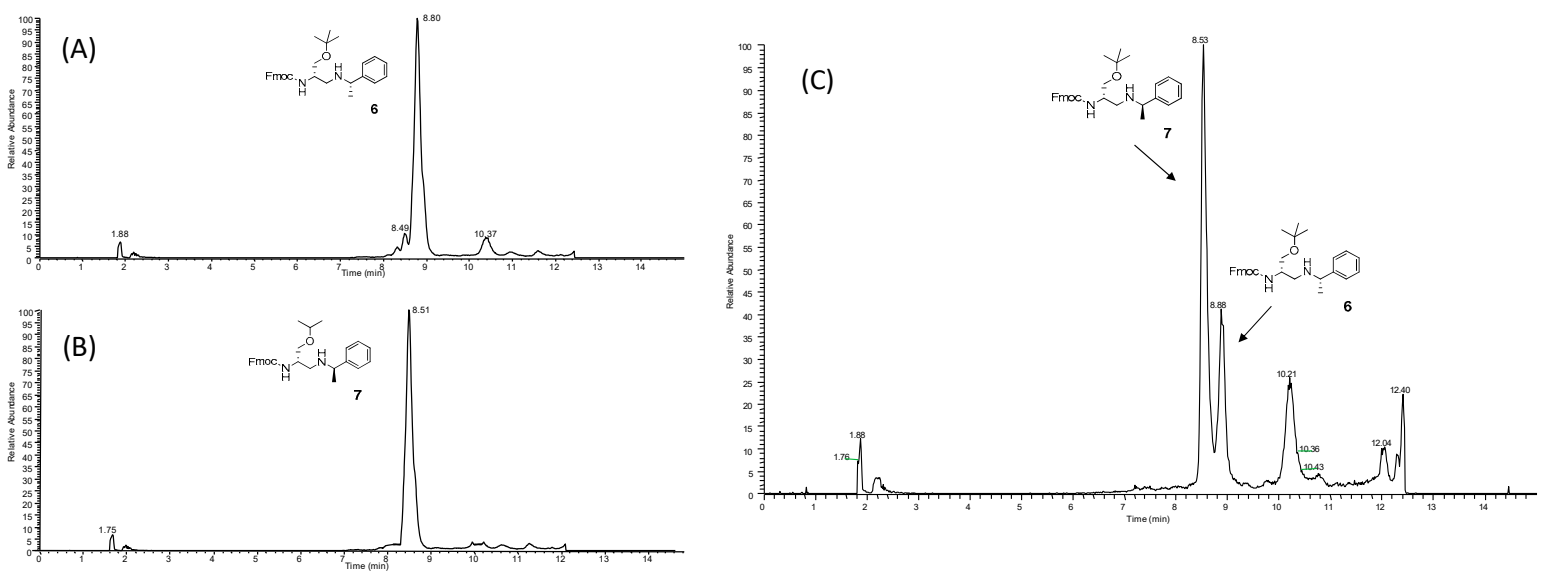

Figure 2. Reverse-phase (RP) U-HPLC/MS analysis of crude 6 (A), crude 7 (B), and a 2:1 mixture of diastereomers 6 and $7(\mathrm{C})$.

\subsection{Reductive Amination of the Aldehyde 3 with Sulfonamides}

We focused our attention on the reductive amination of 3 with $p$-toluenesulfonamide and 4-nitrobenzenesulfonamide (Scheme 2, Table 1). The required nucleophiles were prepared from the corresponding commercial sulfonyl chlorides, via reaction with a $20 \%$ ammonia solution. Reductive amination of $\mathbf{3}$ produced the arylsulfonyl-protected 2,3-diaminopropanols 9 and 10, in very high yields ( $82 \%$ and $85 \%$, respectively), after column chromatography. NMR spectroscopy and mass spectrometry experiments confirmed the structures of both compounds. The successive treatment of 9 with a slight excess of trimethyloxonium tetrafluoroborate [72,73] was site-specific, furnishing $\mathbf{1 1}$ as the unique product of methylation, in a quantitative yield, and without need for chromatography (Scheme 3).<smiles>CC(C)(C)OC[C@H](CNS(=O)(=O)c1ccc([N+](=O)[O-])cc1)NC(F)F</smiles><smiles>CN(C[C@H](COC(C)(C)C)NC(F)F)S(=O)(=O)c1ccc([N+](=O)[O-])cc1</smiles>

Scheme 3. Methylation of 9. Experimental conditions: $\left(\mathrm{CH}_{3} \mathrm{O}\right)_{3} \mathrm{BF}_{4} / \mathrm{DIEA} / \mathrm{DCM}, 10 \mathrm{~min}$, r.t. (quantitative yield).

Alternatively, methylation of 9 was realized using a threefold excess of diazomethane in dichloromethane, at room temperature. In this case, compound $\mathbf{1 1}$ was obtained, in short times, in quantitative yields, and avoiding chromatography. However, for a gram-scale preparation, diazomethane might be not the best option, because of its toxicity and dangerous preparation [74]. Compound 11 was reputed to be a possible intermediate for the synthesis of $N^{\beta}$-methylated L-Dap scaffolds, after transformation of the $\mathrm{OH}$ function into a carboxyl group, followed by the final removal of the arylsulfonyl protection.

\subsection{Synthesis of the $\mathrm{L}-$ Dap methyl Ester $\mathbf{1 4}$}

The 2,3-aminopropanol 10 featured three orthogonal masking groups, a favorable characteristic for completing the L-Dap backbone realization. The presence of a tosyl group, which is largely employed in amino acid chemistry and peptide synthesis $[75,76]$, convinced us to select $\mathbf{1 0}$ as the most likely candidate for the development of a short synthetic route to the desired L-Dap backbone. We designed an economical and mild method, which can limit chromatography and preserve sensitive masking groups. 
The synthetic procedure is depicted in Scheme 4. Initially, the 2,3-diaminopropanol 10 was reacted with trifluoroacetic acid (TFA) in the presence of trifluoroethanol (TFE). Acidolysis of the tert-butyl ether moiety generated the 2,3-diaminopropanol 12, which was quantitatively obtained without need for chromatography. Compound 12 was then subjected to oxidation with 1,3,5-trichloro-2,4,6-triazinetrione; trichloroisocyanuric acid (TCCA) in the presence of catalytic amounts of (2,2,6,6-tetramethylpiperidi-1-yl)oxyl (TEMPO) and sodium bromide, to afford 13. The crude carboxylic acid was finally treated with diazomethane in dichloromethane at room temperature, to give the L-Dap methyl ester 14, which was obtained in an excellent overall yield, without chromatography.

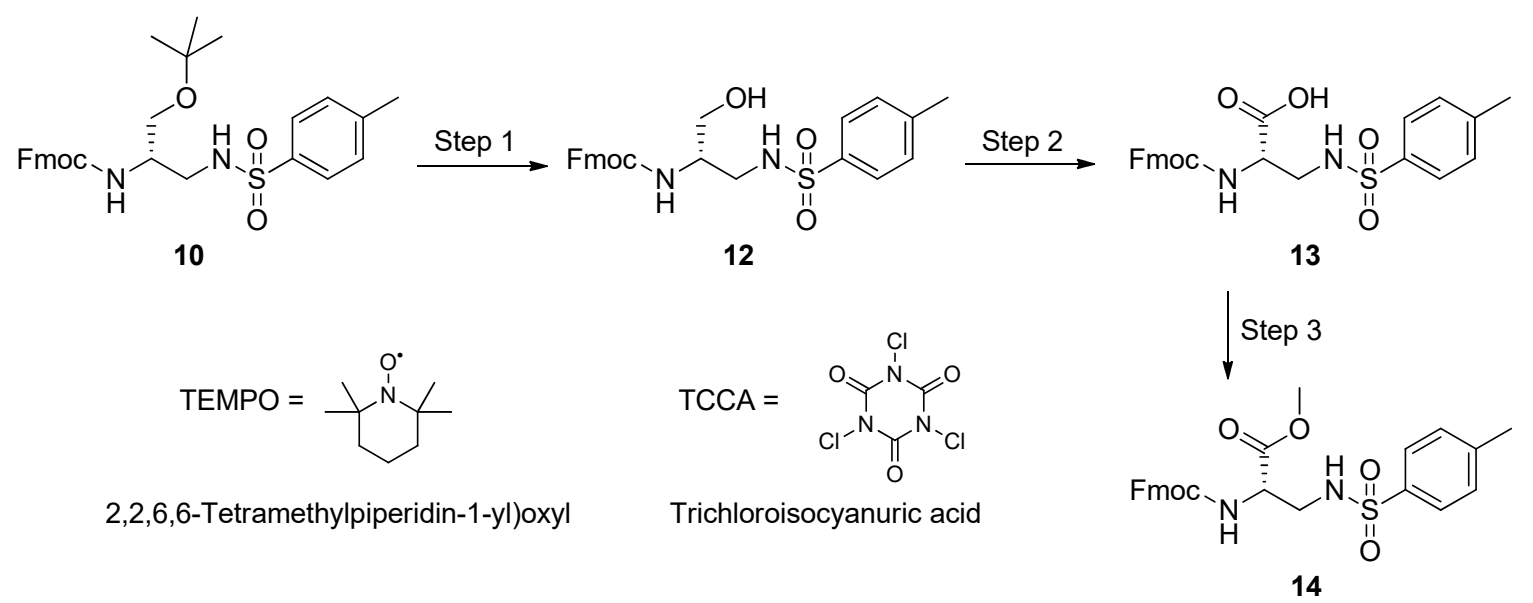

Scheme 4. Oxidation of 10 with; 1,3,5-trichloro-2,4,6-triazinetrione (trichloroisocyanuric acid, TCCA)/ (2,2,6,6-tetramethylpiperidi-1-yl)oxyl (TEMPO): preparation of Fmoc-L-Dap(Ts)-OCH 3 (14) Experimental conditions: Step 1 (acydolysis), Trifluoroacetic acid (TFA)/Trifluoroethanol (TFE)/DCM, $15 \mathrm{~min}$, r.t. (quantitative yield); Step 2 (oxidation), TCCA/TEMPO/NaBr/aq. $\mathrm{NaHCO}_{3} /$ Acetone, $20 \mathrm{~min}$. at $0{ }^{\circ} \mathrm{C}$, then overnight, r.t.; Step 3 (methylation), $0.66 \mathrm{~N} \mathrm{CH}_{2} \mathrm{~N}_{2}$ in $\mathrm{DCM}, 15 \mathrm{~min}$, r.t. (14, yields: $92 \%$ over 2 steps, and $68 \%$ referred to the initial amount of $\mathbf{1}$ ).

\subsection{Synthesis of the L-Dap Methyl Ester $\mathbf{2 1}$}

Continually, we investigated the applicability of the TEMPO-mediated oxidation to the preparation of a L-Dap methyl ester, bearing the acid-sensitive Boc and the base-labile Fmoc group on the 2- and 3- $\mathrm{NH}_{2}$ functions, respectively. We were attracted by the idea of masking the side-chain amino function of L-Dap with the Fmoc group, because this protection can easily be removed under mild conditions during amino acid coupling sequences in solution phase and/or on solid supports, generally used in the total synthesis of oligopeptide strands and biologically active peptides. To fulfill our aim, we turned our attention on the benzyl-protected 2,3-diaminopropan-1-ol 4. The presence of the benzyl group is beneficial, because it can effortlessly be removed by catalytic hydrogen transfer, preserving sensitive functional groups, base- and acid-labile masking moieties, and the chiral integrity of neighboring chiral carbon atoms. We planned a multi-step procedure, which could sequentially employ only crude products, as they are obtained via the simple work-up of the respective reactions, minimizing the number of time-expending and tedious chromatographic purifications. Scheme 5 displays the synthetic approach used to convert 4 into the targeted fully protected L-Dap methyl ester $\mathbf{2 1}$. 


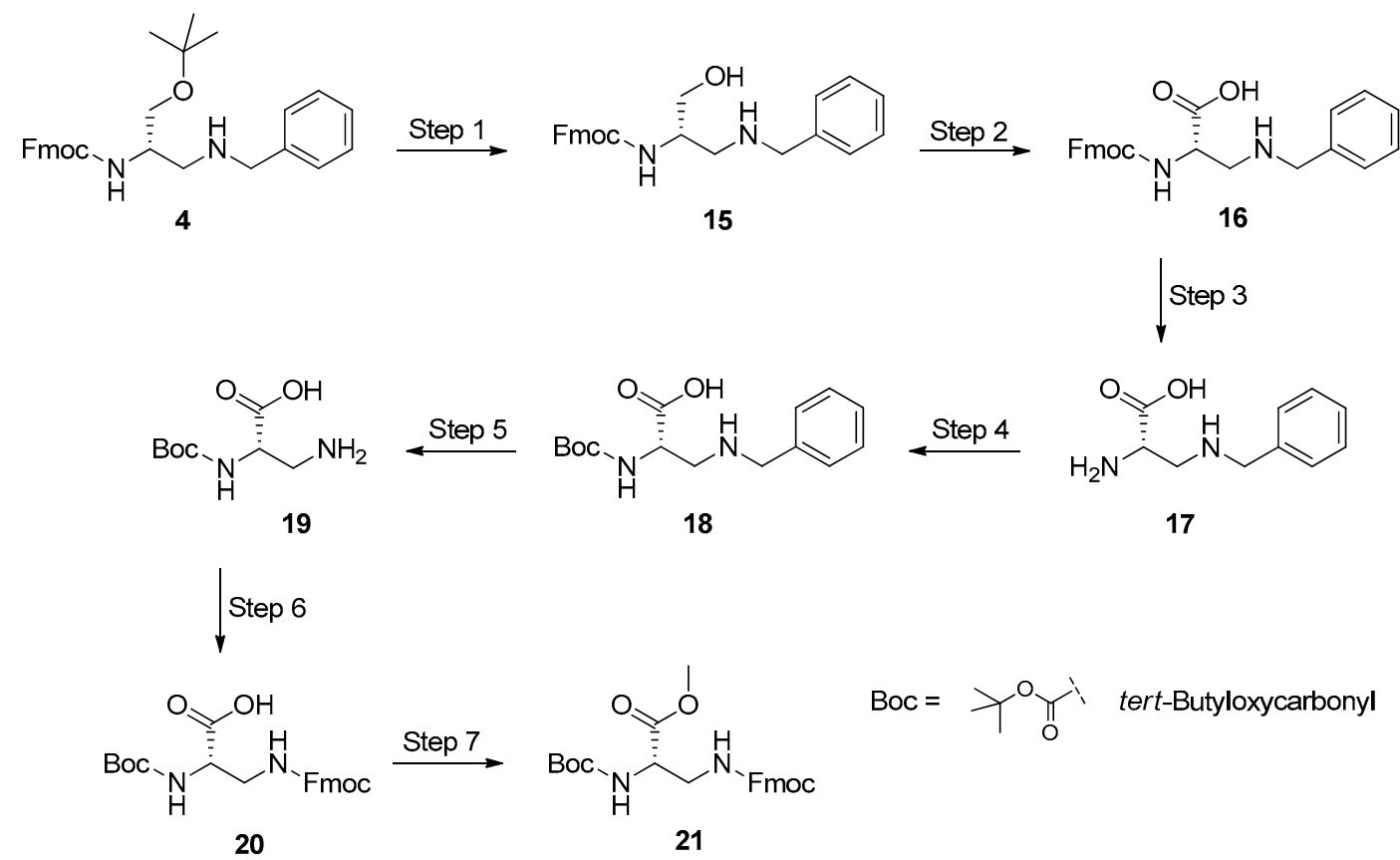

Scheme 5. Multistep synthesis of Boc-L-Dap(Fmoc)-OH (20) and its derivative Boc-L-Dap(Fmoc)-OCH (21). Experimental conditions: Step 1 (acidolysis), TFA/TFE/DCM, 15 min, r.t.; Step 2 (oxidation), TCCA/TEMPO/NaBr/aq. $\mathrm{NaHCO}_{3} /$ Acetone, $20 \mathrm{~min}$ at $0{ }^{\circ} \mathrm{C}$, then overnight, r.t.; Step 3 (Fmoc removal), $20 \%$ DEA in DCM, 30 min, r.t.; Step 4 (protection with Boc), $\mathrm{Boc}_{2} \mathrm{O} / \mathrm{H}_{2} \mathrm{O} / 1$,4-dioxane $/ \mathrm{NaHCO}_{3}$, overnight, r.t.; Step 5 (hydrogenolysis), 1,4-cyclohexene/10\% Pd-C/EtOH, overnight, $25^{\circ} \mathrm{C}$; Step 6 (protection with Fmoc), Fmoc-OSu/ $\mathrm{H}_{2} \mathrm{O} / 1$, 4-dioxane/ $\mathrm{NaHCO}_{3}$, overnight, r.t.; Step 7 (methylation), $0.66 \mathrm{~N} \mathrm{CH}_{2} \mathrm{~N}_{2}$ in DCM, 15 min, r.t. (Yields: 20, 93\% over 6 steps, and 73\% referred to the initial amount of 1; 21, quantitative from 20).

The conversion of 4 into 20 began with the acidolysis of the tert-butyl ether linkage, to generate 15. Unlike the synthesis of methyl ester $\mathbf{1 4}$, we preferred to directly oxidize the crude intermediate 2,3-diaminopropanol 15, without further purification. The reagent system TCCA/TEMPO/NaBr was used to obtain 16, which was in turn treated with diethylamine (DEA) in dichloromethane, to remove the Fmoc protecting group. Unblocking of the 2- $\mathrm{NH}_{2}$ function afforded the carboxylic acid 17, which was subsequently reacted with di-tert-butyl dicarbonate $\left(\mathrm{Boc}_{2} \mathrm{O}\right)$ to yield the Boc-derivative 18 . A catalytic transfer hydrogenation step [77] was applied to remove the benzyl residue from the $3-\mathrm{NH}_{2}$ function of 18, and the obtained carboxylic acid 19 was reacted with ( $N$-(9-fluorenylmethoxycarbonyloxy)succinimide) (Fmoc-OSu), to afford the fully protected amino acid 20 in very high overall yields, after chromatography. ${ }^{1} \mathrm{H}$ - and ${ }^{13} \mathrm{C}-\mathrm{NMR}$ spectroscopy showed all proton and carbon resonances as expected for the structure of 20. At this point, we decided to check whether the chirality of the asymmetric carbon is preserved after the oxidation and unblocking/protection steps. Polarimetric measurements performed on a sample of pure $\mathbf{2 0}$ furnished an optical rotation similar to that obtained for a commercial specimen of the same compound, at the same concentration. The methyl ester 21 was quantitatively obtained by treating 20 with a slight excess of diazomethane in dichloromethane. NMR spectroscopy confirmed the molecular structure of $\mathbf{2 1}$, and its optical rotation was almost equal to that reported in the literature for the same optically pure compound prepared by a different procedure [51], within experimental error. This finding unambiguously proved that racemization does not occur in our synthesis of L-Dap, preserving the chirality of $\mathbf{1}$ throughout the applied multistep procedure. 


\subsection{Couplings of L-Dap Methyl Ester 21}

As the conclusive point of our study, the L-Dap methyl ester $\mathbf{2 1}$ was subjected to couplings with both enantiomerically pure $\mathrm{L}$ and D optical isomers of Fmoc-Ala-OH, to obtain dipeptides $\mathbf{2 3}$ and $\mathbf{2 4}$ (Scheme 6).

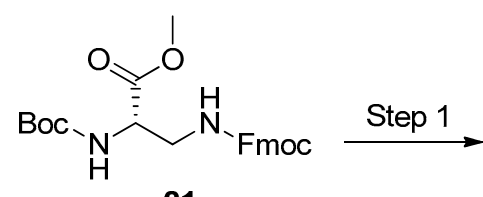

21

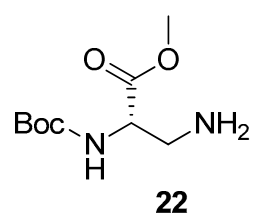

22

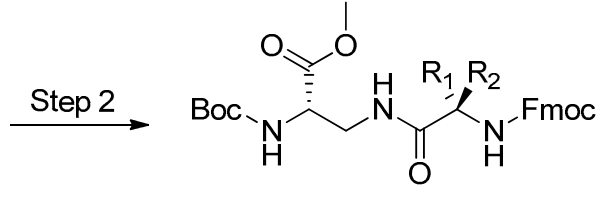

23: $\mathrm{R}_{1}=\mathrm{H}, \mathrm{R}_{2}=\mathrm{CH}_{3}$

24: $\mathrm{R}_{1}=\mathrm{CH}_{3}, \mathrm{R}_{2}=\mathrm{H}$

Scheme 6. Side-chain elongation of 21: preparation of dipeptides 23 and 24. Experimental conditions: Step 1 (Fmoc removal), 20\% DEA in DCM, 30 min, r.t.; Step 2 (coupling): Fmoc-L-Ala-OH or Fmoc-D-Ala-OH, HOBt monohydrate/EDC/DIEA/DCM, overnight, r.t.

This experiment was performed in order to verify the possible use of 21 in solution-phase Fmoc-chemistry-based peptide synthesis, and to check whether racemization of $\mathbf{2 1}$ occurs during the coupling process. Diastereomers 23 and 24 were prepared via a classical solution-phase strategy [78]. Accordingly, 21 was treated with DEA to unblock the $3-\mathrm{NH}_{2}$ group, and then separately coupled to both $\mathrm{N}$-Fmoc-alanine enantiomers. The system 1-(3-dimethylaminopropyl)-3-ethylcarbodiimide hydrochloride/1-hydroxybenzotriazole $(\mathrm{EDC} / \mathrm{HOBt})$ was adopted to activate the carboxyl function of both protected alanine enantiomers, in the presence of the Hunig's base (diisopropylethylamine, DIEA). Reactions gave dipeptides 23 and $\mathbf{2 4}$, which were directly analyzed by RP U-HPLC/MS (see Supplementary Materials), without pre-injection purification. Instrumental analysis highlighted that only one product was obtained from each coupling, confirming that the experimental conditions adopted for the side-chain elongation of $\mathbf{2 1}$ proceeded without detectable changes of its chirality.

\section{Materials and Methods}

Chemicals and solvents were reagent and HPLC grade (Sigma-Aldrich, Milano, Italy); amino acids were purchased from Senn Chemicals (Bülack, Switzerland). All reagents were used without further purification. Solvents (Sigma-Aldrich, Milano, Italy) were purified according to standard procedures, and freshly distilled under a dry nitrogen current, prior to use. Petroleum ether $60-80{ }^{\circ} \mathrm{C}$ was used for TLC and column chromatography. Melting points were determined by a Kofler hot-stage apparatus (Reichert-Thermovar, Germany), at atmospheric pressure, and they are uncorrected. Optical rotations were measured in a $1-\mathrm{dm}^{3}$ (2-mL volume) tube, in methanol (c 1.0), and $[\alpha]_{\mathrm{D}}$ values were determined at $20^{\circ} \mathrm{C}$, using a digital polarimeter. All NMR spectra were recorded at $25 \pm 0.1^{\circ} \mathrm{C}$, using 5 -mm tubes (seven inches in length), on an Avance 300 Ultrashielded Spectrometer (Bruker Biospin, Milano, Italy), equipped with a BB0 probe and a temperature control unit. One-dimensional ${ }^{1} \mathrm{H}$ - and ${ }^{13} \mathrm{C}-\mathrm{NMR}$ spectra were recorded at $300.132 \mathrm{MHz}$ and $75.03 \mathrm{MHz}$, respectively. Deuterated chloroform for spectroscopy $\left(\mathrm{CDCl}_{3}, 99.5 \%\right.$ isotopically pure, containing $0.1 \%$ tetramethylsilane (TMS)) was used as the solvent for all spectral analysis. Chemical shifts $(\delta)$ are reported in parts per million (ppm), and they are referred to the resonance of the residual proton of the solvent (singlet at $7.25 \mathrm{ppm}$ ) and to the central line $(77.0 \mathrm{ppm})$ of the solvent triplet, in proton and carbon spectra, respectively. Proton coupling constants $(J)$ are reported in Hz. Relaxation times $\left(\mathrm{T}_{1}\right)$ for all ${ }^{1} \mathrm{H}$ and ${ }^{13} \mathrm{C}$ carbon nuclei were calculated experimentally for all synthesized compounds, using a pulse sequence and method as published in the literature [79] and fixed to the superior limits of $3 \mathrm{~s}$ (proton) and $10 \mathrm{~s}$ (carbon). Extensive proton decoupling experiments were applied to unequivocally assign all resonances to the respective protons. Two-dimensional homonuclear correlation spectra $\left({ }^{1} \mathrm{H},{ }^{1} \mathrm{H}\right.$-TOCSY $)$ were obtained by the M.Levitt's composed pulse decoupling sequence (MLEV) for isotropic conditions, with an $80 \mathrm{~ms}$ 
spin-lock period, elaborating spectral data as previously reported [80]. Acquisition and elaboration parameters for one-dimensional ${ }^{1} \mathrm{H}$ and ${ }^{13} \mathrm{C}$ spectra were as already published [81]. Reverse-phase ultrafast HPLC/mass spectrometry (RP U-HPLC/MS) was carried out using a Vantage RP U-HPLC instrument (Thermo), coupled to a triple quadrupole mass spectrometer and equipped with a heated electrospray ion source (HESI II), which operated in positive mode [82]. Chromatographic runs were obtained on a C-18 RP analytical column (Hypersyl Gold, $2.1 \times 50 \mathrm{~mm}$, particle size $1.9 \mu \mathrm{m}$ ), under isocratic conditions and with a $0.4 \mathrm{~mL} / \mathrm{min}$ flux, applying a 55:45 water (containing $0.1 \%$ TFA)/methanol elution gradient. ESI(+) MS spectra were obtained by a Q-star $i$-pulsar instrument (AB Sciex), operated in positive mode at $20 \mathrm{keV}$, and equipped with a TOF ion analyzer [82]. HRMS analyses were performed using a MALDI-TOF/TOF 5800 spectrometer (AB Sciex), in reflectron positive mode [83,84]. Reactions were monitored by thin-layer chromatography (TLC), using pre-coated silica gel glass plates (Merck, $60-\mathrm{F} 254,0.25 \mathrm{~mm}$ ). The best elution of carboxylic acids was obtained by adding glacial acetic acid (three drops) to the eluent mixture ( $5 \mathrm{~mL}$ ). Chromatographic spots were visualized with an ultraviolet (UV) lamp (254 nm), ninhydrine ( $0.2 \%$ in $n$-butanol), vanilline solution ( $5 \%$ in ethanol $\left./ \mathrm{H}_{2} \mathrm{SO}_{4}\right)$, and $\mathrm{H}_{2} \mathrm{SO}_{4}$ ( $20 \%$ in absolute ethanol). After elution, charring at $200{ }^{\circ} \mathrm{C}$ was applied to develop spot colorations. Kieselgel $60 \mathrm{H}$ without gypsum (Merck) was used as the stationary phase for short-column flash chromatography, adopting the same gradients used for the respective TLC analyses, with the polar component being reduced four-fold. All reactions were carried out with pre-flamed glassware and under an inert atmosphere (dry $\left.\mathrm{N}_{2}\right)$. Diazomethane in DCM $(0.66 \mathrm{M}$ solution) was freshly prepared starting from $\mathrm{N}$-methyl- $\mathrm{N}$-nitrosourea, accordingly to the published procedure [74], and then stored on $\mathrm{KOH}$ pellets at $-20^{\circ} \mathrm{C}$. Diazomethane concentration was obtained by back-titration with a standard solution of benzoic acid.

\subsection{Synthesis of the Weinreb-Nahm Amide 2}

HOBt monohydrate $(239.6 \mathrm{mg}, 1.57 \mathrm{mmol})$, DIC $(0.24 \mathrm{~mL}, 1.57 \mathrm{mmol})$, and DIEA $(0.27 \mathrm{~mL}$, $1.57 \mathrm{mmol})$ were added to a solution of $N^{\alpha}$-Fmoc-O-tert-butyl-D-serine $(\mathbf{1} ; 500 \mathrm{mg}, 1.30 \mathrm{mmol})$ in dry DCM $(5 \mathrm{~mL})$, under magnetic stirring. After $2 \mathrm{~h}$ at room temperature, a solution of $\mathrm{N}, \mathrm{O}$-dimethylhydroxylamine hydrochloride $(127.2 \mathrm{mg}, 1.304 \mathrm{mmol})$ and DIEA (1.2 equivalents, $0.27 \mathrm{~mL}, 1.57 \mathrm{mmol})$ in dry DCM $(5 \mathrm{~mL})$ was added dropwise, and the resulting mixture was maintained under magnetic stirring overnight at room temperature (TLC: diethyl ether/petroleum ether, 80:20 v/v). The solvent was removed under reduced pressure condition, and the recovered solid residue was re-dissolved in $5 \%$ aqueous $\mathrm{NaHSO}_{4}(10 \mathrm{~mL})$, then extracted with diethyl ether $(3 \times 10 \mathrm{~mL})$. The organic layers were washed with $5 \%$ aqueous $\mathrm{NaHCO}_{3}(3 \times 10 \mathrm{~mL})$ and brine $(3 \times 10 \mathrm{~mL})$, dried over $\mathrm{Na}_{2} \mathrm{SO}_{4}$, paper filtered, and evaporated to dryness under reduced pressure conditions. The crude product was purified by flash column chromatography (FCC) eluent: diethyl ether/petroleum ether, 95:5 v/v), to obtain the title product. White solid (522.7 mg, 94\%), mp $136-138{ }^{\circ} \mathrm{C} ;{ }^{1} \mathrm{H}-\mathrm{NMR}(300 \mathrm{MHz}$, $\left.\mathrm{CDCl}_{3}\right) \delta 7.75(\mathrm{~d}, 2 \mathrm{H}, J=7.0$, ArH Fmoc), 7.61 (d, 2H, $J=7.0$, ArH Fmoc), $7.38(\mathrm{t}, 2 \mathrm{H}, J=7.0$, ArH Fmoc), $7.30(\mathrm{t}, 2 \mathrm{H}, J=7.0$, ArH Fmoc), $5.86(\mathrm{~d}, 1 \mathrm{H}, J=7.2, \mathrm{NH}), 4.88(\mathrm{bs}, 1 \mathrm{H}, \mathrm{CHNH}), 4.36(\mathrm{~d}, 2 \mathrm{H}, J=6.9$, $\mathrm{CH}_{2}$ Fmoc), $4.23\left(\mathrm{t}, 1 \mathrm{H}, J=6.9, \mathrm{CH}\right.$ Fmoc), $1.16\left(\mathrm{~s}, 9 \mathrm{H}, \mathrm{CH}_{3} \mathrm{tBu}\right) ;{ }^{13} \mathrm{C}-\mathrm{NMR}\left(75 \mathrm{MHz}, \mathrm{CDCl}_{3}\right) \delta 170.6$, 155.9, 143.7, 141.1, 127.5, 126.9, 115.0, 119.7, 73.4, 66.9, 61.8, 61.3, 51.6, 46.9, 32.0, 27.1; MALDI HRMS: calculated 427.2227 for $\mathrm{C}_{24} \mathrm{H}_{31} \mathrm{~N}_{2} \mathrm{O}_{5}{ }^{+}$, found 427.2244.

\subsection{Synthesis of the Aldehyde 3}

A solution of $2(522,7 \mathrm{mg}, 1.23 \mathrm{mmol})$ in dry THF was treated with $\mathrm{LiAlH}_{4}(93.1 \mathrm{mg}, 2.45 \mathrm{mmol})$, under magnetic stirring at room temperature. Reaction was complete in $12 \mathrm{~min}$, as checked by TLC (diethyl ether/petroleum ether 70:30, v/v). A 5\% aqueous solution of $\mathrm{NaHCO}_{3}$ was added (CAUTION), and the mixture was stirred for $10 \mathrm{~min}$. The ethereal phase was separated, and the aqueous residue was washed with fresh diethyl ether $(3 \times 10 \mathrm{~mL})$. The organic extracts were collected, washed with a $5 \%$ aqueous solution of $\mathrm{NaHSO}_{4}(3 \times 10 \mathrm{~mL})$ and once with brine $(10 \mathrm{~mL})$, dried over $\mathrm{Na}_{2} \mathrm{SO}_{4}$, paper-filtered, and evaporated to dryness under reduced pressure conditions, to give 3 . The aldehyde 
was pure enough and was used in the next step without further purification. Colorless oil (415.3 mg, 92\%); TLC (diethyl ether/petroleum ether 70:30, v/v): $\mathrm{R}_{f}=0.65 ;{ }^{1} \mathrm{H}-\mathrm{NMR}\left(300 \mathrm{MHz}, \mathrm{CDCl}_{3}\right) \delta 9.63$ $(\mathrm{d}, 1 \mathrm{H}, J=2.8, \mathrm{CHO}), 7.75(\mathrm{~d}, 2 \mathrm{H}, J=7.0, \mathrm{ArH}), 7.62(\mathrm{~d}, 2 \mathrm{H}, J=7.0, \mathrm{ArH}), 7.40(\mathrm{t}, 2 \mathrm{H}, J=7.0, \mathrm{ArH})$, $7.32(\mathrm{t}, 2 \mathrm{H}, J=7.0, \mathrm{ArH}), 5.71(\mathrm{~d}, 1 \mathrm{H}, J=6.0, \mathrm{NH}), 4.42\left(\mathrm{~d}, 2 \mathrm{H}, J=7.1, \mathrm{CH}_{2}\right.$ Fmoc $) 4.32-4.38(\mathrm{~m}, 1 \mathrm{H}$, $\mathrm{CHNH}), 4.25\left(\mathrm{t}, 1 \mathrm{H}, J=7.1, \mathrm{CH}\right.$ Fmoc), $3.96\left(\mathrm{dd}, 1 \mathrm{H}, J=11.2\right.$ and 7.6, $\left.\mathrm{CH}_{2} \mathrm{O}\right), 3.63(\mathrm{dd}, 1 \mathrm{H}, J=11.2$ and 5.8, $\left.\mathrm{CH}_{2} \mathrm{O}\right), 1.16\left(\mathrm{~s}, 9 \mathrm{H}, \mathrm{CH}_{3}\right) ;{ }^{13} \mathrm{C}-\mathrm{NMR}\left(75 \mathrm{MHz} \mathrm{CDCl}_{3}\right) \delta 199.1,156.1,143.7,141.2,127.7,127.0$, 125.0, 119.9, 73.7, 67.1, 60.4, 59.9, 47.0, 27.1; MALDI HRMS: calculated for $\mathrm{C}_{22} \mathrm{H}_{26} \mathrm{NO}_{4}{ }^{+} 368.1858$, found 368.1869 .

\subsection{Synthesis of 4-10. General Procedure for the Reductive Amination}

To a solution of $3(206.6 \mathrm{mg}, 0.56 \mathrm{mmol})$ in dry ethanol $(4 \mathrm{~mL}), \mathrm{Ti}(\mathrm{OiPr})_{4}(0.34 \mathrm{~mL}, 1.12 \mathrm{mmol})$ was added under magnetic stirring at room temperature. After $10 \mathrm{~min}$, the appropriate primary amine or arylsulfonylamide $(0.67 \mathrm{mmol})$ was added. The resulting mixture was maintained under stirring at room temperature until complete conversion of 3, monitoring the imine formation by TLC (diethyl ether/petroleum ether, 80:20 v/v), and $\mathrm{NaBH}_{3} \mathrm{CN}(52.8 \mathrm{mg}, 0.84 \mathrm{mmol}$ ) was added. The mixture was stirred overnight at room temperature, and brine $(5 \mathrm{~mL})$ was then added. The white precipitate was filtered off by paper filtration and washed with a minimum amount of absolute ethanol. The mother liquor was concentrated under reduced pressure conditions, and the residue was eluted with ethyl acetate through a short pad of Celite $545^{\circledR}$. The organic solution was dried over $\mathrm{MgSO}_{4}$, paper-filtered, and evaporated to dryness under vacuum, to give a crude material that was fractioned by column chromatography (eluent: AcOEt/n-hexane, 50:50 v/v, reducing the polar component four-fold), to deliver the desired 2,3-diaminopropanols 4-10 in an 82\%-92\% overall yield.

2,3-Diaminopropanol 4. Colorless oil (236.9 mg, 92\%); TLC (diethyl ether $/ n$-hexane 80:20, $v / v): \mathrm{R}_{f}=$ 0.17; ${ }^{1} \mathrm{H}-\mathrm{NMR}\left(300 \mathrm{MHz}, \mathrm{CDCl}_{3}\right) \delta 7.76$ (d, 2H, J = 7.0, ArH Fmoc), 7.60 (d, 2H, J = 7.0, ArH Fmoc), 7.28-7.43 (m, 9H, ArH Fmoc and ArH phenyl), 5.52 (d, 1H, J = 6.8, NHCO), $4.37\left(\mathrm{~d}, 2 \mathrm{H}, J=6.9, \mathrm{CH}_{2}\right.$ Fmoc), $4.22\left(1 \mathrm{H}, J=6.9, \mathrm{CH}\right.$ Fmoc), 3.77-3.92 (m, 4H, CH, $\mathrm{CH}_{2} \mathrm{O}$ and $\left.\mathrm{PhCH}_{2}\right), 3.41-3.49\left(\mathrm{~m}, 1 \mathrm{H}, \mathrm{CH}_{2} \mathrm{O}\right)$, 2.73-2.81 (m, 2H, CH $2 \mathrm{~N}), 2.25-2.40(\mathrm{~m}, 1 \mathrm{H}, \mathrm{NH}), 1.19\left(\mathrm{~s}, 9 \mathrm{H}, \mathrm{CH}_{3} \mathrm{tBu}\right) ;{ }^{13} \mathrm{C}-\mathrm{NMR}\left(75 \mathrm{MHz} \mathrm{CDCl}_{3}\right)$ $\delta$ 156.6, 144.1, 141.2, 136.0, 128.7, 127.93, 127.91, 126.6, 124.7, 124.2, 119.8, 73.7, 68.5, 66.8, 55.4, 52.8, 48.0, 47.1, 27.1; ESI(+) MS: $m / z$ 459.38 [M + H] ${ }^{+}$; MALDI HRMS: calculated for $\mathrm{C}_{29} \mathrm{H}_{35} \mathrm{~N}_{2} \mathrm{O}_{3}{ }^{+} 459.2642$, found 459.2658 .

2,3-Diaminopropanol 5. Pale yellow oil (280.2 mg,90\%); TLC (diethyl ether/ $n$-hexane 80:20, v/v): $\mathrm{R}_{f}=$ 0.25; ${ }^{1} \mathrm{H}-\mathrm{NMR}\left(300 \mathrm{MHz}, \mathrm{CDCl}_{3}\right)$ severe overlap, 75:25 mixture of two conformers, $\delta 7.79(\mathrm{~d}, 4 \mathrm{H}, \mathrm{J}=6.9$, ArH Fmoc), 7.65 (d, 4H, J = 6.9, ArH Fmoc), 7.19-7.49 (m, 28H, ArH Fmoc and ArH phenyls), 5.76 (d, $0.25 \mathrm{H}, J=8.9$, NHCO minor conformer), $5.55(\mathrm{~d}, 0.75 \mathrm{H}, J=7.2, \mathrm{NHCO}$ major conformer), 4.86 (sb, $2 \mathrm{H}$, $\left.\mathrm{CHPh}_{2}\right), 4.44-4.48\left(\mathrm{~m}, 0.25 \mathrm{H}, \mathrm{CHNH}\right.$ minor conformer), $4.42\left(\mathrm{~d}, 4 \mathrm{H}, \mathrm{J}=8.0, \mathrm{CH}_{2} \mathrm{Fmoc}_{\text {) }}, 4.22(\mathrm{t}, 2 \mathrm{H}, J\right.$ $=8.0, \mathrm{CH}$ Fmoc), 4.09-4.16 (m, 0.75H, CHNH major conformer), 3.81-3.86 (m, 0.50H, $\mathrm{CH}_{2} \mathrm{O}$ minor conformer), 3.45-3.69 (m, 1.5H, $\mathrm{CH}_{2} \mathrm{O}$ major conformer), 2.70-2.80 (m, 2H, $\mathrm{CH}_{2} \mathrm{~N}$ major conformer), 2.12-2.39 (m, 4H, $\mathrm{CH}_{2} \mathrm{~N}$ minor conformer, and $\mathrm{NH}$ both conformers), $1.17\left(\mathrm{~s}, 18 \mathrm{H}, \mathrm{CH}_{3} t \mathrm{Bu}\right) ;{ }^{13} \mathrm{C}-\mathrm{NMR}$ $\left(75 \mathrm{MHz}_{,} \mathrm{CDCl}_{3}\right) \delta 156.1,155.8,145.3,144.1,143.9,143.7,143.6,143.0,141.2,128.7,128.6,128.4,127.7$, 127.6, 127.5, 127.2, 127.1, 126.90, 126.88, 126.81, 125.0, 124.7, 120.0, 119.9, 73.8, 72.9, 67.2, 67.0, 66.6, 50.8, 50.5, 49.1, 47.2, 47.0, 27.3, 27.2; ESI(+) MS: $m / z 557.72[\mathrm{M}+\mathrm{H}]^{+}$; MALDI HRMS: calculated for $\mathrm{C}_{39} \mathrm{H}_{38} \mathrm{~N}_{2} \mathrm{NaO}_{3}+557.2775$, found 557.2797.

2,3-Diaminopropanol 6. Colorless oil (237.9 mg, 90\%); TLC (diethyl ether/n-hexane 80:20, v/v): $\mathrm{R}_{f}=$ $0.21 ;{ }^{1} \mathrm{H}-\mathrm{NMR}\left(300 \mathrm{MHz}, \mathrm{CDCl}_{3}\right) \delta 7.76$ (d, 2H, J = 7.2 Hz, ArH Fmoc), 7.61 (d, 2H, J = 7.2 Hz, ArH Fmoc), 7.40 (t, 2H, J = 7.2 Hz, ArH Fmoc), 7.20-7.40 (m, 7H, ArH Fmoc and ArH phenyl), 5.43 (d, 1H, $J=7.9, \mathrm{NHCO}), 4.38-4.48$ (m, 1H, CH Fmoc), 4.21-4.36 (m, 2H, $\mathrm{CH}_{2} \mathrm{Fmoc}_{\text {) }}$, 3.68-3.82 (m, 2H, $\mathrm{CH}_{2} \mathrm{O}$ and $\left.\mathrm{CH}_{2} \mathrm{CHNH}\right), 3.54-3.97(\mathrm{~m}, 1 \mathrm{H}, \mathrm{CHNH}), 2.60-2.76\left(\mathrm{~m}, 1 \mathrm{H}, \mathrm{CH}_{2} \mathrm{NH}\right), 2.23-2.46\left(\mathrm{~m}, 2 \mathrm{H}, \mathrm{CH}_{2} \mathrm{NH}\right.$ and $\mathrm{CHNH}), 1.34\left(\mathrm{~d}, 3 \mathrm{H}, \mathrm{J}=6.5, \mathrm{CH}_{3}\right), 1.14\left(\mathrm{~s}, 9 \mathrm{H}, \mathrm{CH}_{3} t \mathrm{Bu}\right) ;{ }^{13} \mathrm{C}-\mathrm{NMR}\left(75 \mathrm{MHz}, \mathrm{CDCl}_{3}\right) \delta 156.3,145.8$, 
143.4, 141.3, 129.4, 128.4, 127.6, 127.5, 127.0, 126.5, 125.0, 119.9, 73.2, 66.9, 62.2, 55.2, 47.4, 42.1, 27.5, 23.4; ESI(+) MS: $m / z 473.42[\mathrm{M}+\mathrm{H}]^{+}$; MALDI HRMS: calculated for $\mathrm{C}_{30} \mathrm{H}_{37} \mathrm{~N}_{2} \mathrm{O}_{3}{ }^{+}$473.2799, found 473.2817.

2,3-Diaminopropanol 7. Colorless oil (240.5 mg, 91\%); TLC (diethyl ether/ $n$-hexane 80:20, $v / v): R_{f}=$ 0.21; ${ }^{1} \mathrm{H}-\mathrm{NMR}\left(300 \mathrm{MHz}, \mathrm{CDCl}_{3}\right) \delta 7.77$ (d, 2H, $J=7.3$, ArH Fmoc), 7.60 (d, 2H, J = 7.3, ArH Fmoc), $7.40(\mathrm{t}, 2 \mathrm{H}, J=7.3$, Ar Fmoc), 7.19-7.39 (m, 7H, ArH Fmoc and ArH phenyl), $5.52(\mathrm{~d}, 1 \mathrm{H}, J=7.8$, $\mathrm{NHCO}), 4.46-4.21\left(\mathrm{~m}, 3 \mathrm{H}, \mathrm{CH}_{2}\right.$ and $\mathrm{CH}$ Fmoc), 3.63-3.92 (m, 2H, $\left.\mathrm{CH}_{2} \mathrm{O}\right), 3.55-3.62\left(\mathrm{~m}, 1 \mathrm{H}, \mathrm{CHCH}_{2} \mathrm{~N}\right.$ and $\mathrm{CHNH}), 2.50-2.72\left(\mathrm{~m}, 3 \mathrm{H}, \mathrm{CH}_{2} \mathrm{~N}\right.$ and $\left.\mathrm{CHNH}\right), 1.16\left(\mathrm{~d}, 3 \mathrm{H}, J=6.8, \mathrm{CH}_{3}\right), 1,13\left(\mathrm{~s}, 9 \mathrm{H}, \mathrm{CH}_{3} t \mathrm{Bu}\right)$; ${ }^{13} \mathrm{C}-\mathrm{NMR}\left(75 \mathrm{MHz}, \mathrm{CDCl}_{3}\right) \delta 157.1,145.8,144.0,141.3,129.4,128.7,127.6,127.5,126.4,126.4,125.3,115.0$, 73.2, 63.0, 53.5, 50.5, 48.8, 47.3, 27.3, 24.2; ESI(+) MS: $m / z$ 473.35 [M + H] ${ }^{+}$; MALDI HRMS: calculated for $\mathrm{C}_{30} \mathrm{H}_{37} \mathrm{~N}_{2} \mathrm{O}_{3}{ }^{+} 473.2799$, found 473.2780 .

2,3-Diaminopropanol 8. Colorless oil (204.3 mg, 89\%); TLC (diethyl ether/n-hexane 80:20, v/v): $\mathrm{R}_{f}=0.14$; ${ }^{1} \mathrm{H}-\mathrm{NMR}\left(300 \mathrm{MHz}, \mathrm{CDCl}_{3}\right) \delta$ 7.65-7.80 (m, 2H, ArH), 7.61 (d, 2H, J = 7.0, ArH), 7.26-7.45 (m, 4H, ArH), 5.63 (bs, $1 \mathrm{H}, \mathrm{NHCO}), 4.38$ (d, 2H, $\left.J=6.9, \mathrm{CH}_{2} \mathrm{Fmoc}\right), 4.23(1 \mathrm{H}, J=6.9, \mathrm{CH} \mathrm{Fmoc}), 3.31-3.45(\mathrm{~m}, 3 \mathrm{H}$, $\mathrm{CH}$ and $\left.\mathrm{CH}_{2} \mathrm{O}\right), 2.51-2.90\left(\mathrm{~m}, 4 \mathrm{H}, \mathrm{CH}_{2} \mathrm{~N}\right), 1.30-1.58\left(\mathrm{~m}, 2 \mathrm{H}, \mathrm{CH}_{2} \mathrm{CH}_{3}\right), 1.16\left(\mathrm{~s}, 9 \mathrm{H}, \mathrm{CH}_{3} t \mathrm{Bu}\right), 0.75-0.90$ $\left(\mathrm{m}, 3 \mathrm{H}, \mathrm{CH}_{3} \mathrm{CH}_{2}\right) ;{ }^{13} \mathrm{C}-\mathrm{NMR}\left(75 \mathrm{MHz}, \mathrm{CDCl}_{3}\right) \delta 156.2,143.7,141.3,127.8,127.2,125.0,124.8,119.9$, 75.6, 67.5, 52.0, 48.3, 27.2, 21.6, 11.9; ESI(+) MS: $m / z 411.29[\mathrm{M}+\mathrm{H}]^{+}$; MALDI HRMS: calculated for $\mathrm{C}_{25} \mathrm{H}_{35} \mathrm{~N}_{2} \mathrm{O}_{3}{ }^{+} 411.2642$, found 411.2660 .

2,3-Diaminopropanol 9. Pale yellow solid (253.9 mg, 82\%); TLC (diethyl ether $/ n$-hexane 80:20, $v / v$ ): $R_{f}$ $=0.24 ; \mathrm{mp} 127-129^{\circ} \mathrm{C} ;{ }^{1} \mathrm{H}-\mathrm{NMR}\left(300 \mathrm{MHz}, \mathrm{CDCl}_{3}\right) \delta 8.20-8.34\left(\mathrm{~m}, 2 \mathrm{H}, \mathrm{SO}_{2} \mathrm{ArH}\right), 7.90-8.10(\mathrm{~m}, 2 \mathrm{H}$, $\mathrm{SO}_{2} \mathrm{ArH}$ ), 7.76 (d, 2H, J = 7.2, ArH Fmoc), 7.55 (d, 2H, $J=7.2$, ArH Fmoc), 7.33-7.44 (m, 2H, ArH Fmoc), 7.20-7.32 (m, 2H, ArH Fmoc), 5.88 (bs, 1H, $\mathrm{NHSO}_{2}$ ), 5.32 (d, 1H, J = 7.6, NHCO), 4.35-4.49 (m, 1H, $\mathrm{CHNH}), 4.29-4.35$ (m, 2H, CH $\mathrm{Fmoc}), 4.10-4.19$ (m, 1H, CH Fmoc), 4.00-4.09 (m, 1H, $\left.\mathrm{CH}_{2} \mathrm{O}\right), 3.73-3.87$ $\left(\mathrm{m}, 1 \mathrm{H}, \mathrm{CH}_{2} \mathrm{O}\right), 3.15-3.31\left(\mathrm{~m}, 1 \mathrm{H}, \mathrm{CH}_{2} \mathrm{~N}\right), 3.00-3.15\left(\mathrm{~m}, 1 \mathrm{H}, \mathrm{CH}_{2} \mathrm{~N}\right), 1.16\left(\mathrm{~s}, 9 \mathrm{H}, \mathrm{CH}_{3} t \mathrm{Bu}\right) ;{ }^{13} \mathrm{C}-\mathrm{NMR}$ $\left(75 \mathrm{MHz}, \mathrm{CDCl}_{3}\right) \delta 156.4,150.0,145.9,143.7,141.3,128.2,127.8,127.0,124.9,124.3,120.0,73.9,67.1,62.3$, 50.1, 47.1, 42.1, 27.3; ESI(+) MS: $m / z 554.38[\mathrm{M}+\mathrm{H}]^{+}$; MALDI HRMS: calculated for $\mathrm{C}_{28} \mathrm{H}_{32} \mathrm{~N}_{3} \mathrm{O}_{7} \mathrm{~S}^{+}$ 554.1955 , found 554.1938 .

2,3-Diaminopropanol 10. White solid (239.7 mg, 85\%); TLC (diethyl ether $/ n$-hexane 80:20, $v / v$ ): $\mathrm{R}_{f}=$ 0.22; mp 119-121 ${ }^{\circ} \mathrm{C} ;{ }^{1} \mathrm{H}-\mathrm{NMR}\left(300 \mathrm{MHz}, \mathrm{CDCl}_{3}\right) \delta$ 7.68-7.80 (m, 4H, $\left.\mathrm{SO}_{2} \mathrm{ArH}\right), 7.58(\mathrm{~d}, 2 \mathrm{H}, J=7.4$, ArH Fmoc), 7.40 (t, 2H, $J=7.4$, ArH Fmoc), 7.23-7.35 (m, 4H, SO ${ }_{2} \mathrm{ArH}$ and ArH Fmoc), 5.32-5.48 (m, $2 \mathrm{H}, \mathrm{NHCO}$ and $\mathrm{NHSO}_{2}$ ), 4.33 (d, 2H, $\left.J=7.2, \mathrm{CH}_{2} \mathrm{Fmoc}\right), 4.19$ (t, 1H, $J=7.2, \mathrm{CH}$ Fmoc), 3.75-3.85 (m, $1 \mathrm{H}, \mathrm{CHNH}), 3.40-3.50\left(\mathrm{~m}, 2 \mathrm{H}, \mathrm{CH}_{2} \mathrm{O}\right), 3.16-3.28\left(\mathrm{~m}, 1 \mathrm{H}, \mathrm{CH}_{2} \mathrm{~N}\right), 3.00-3.11\left(\mathrm{~m}, 1 \mathrm{H}, \mathrm{CH}_{2} \mathrm{~N}\right), 2.37(\mathrm{~s}, 3 \mathrm{H}$, $\mathrm{CH}_{3}$ tosyl), 1.15 (s, 9H, $\left.\mathrm{CH}_{3} t \mathrm{Bu}\right) ;{ }^{13} \mathrm{C}-\mathrm{NMR}\left(75 \mathrm{MHz}_{2} \mathrm{CDCl}_{3}\right) \delta 156.2,141.2,136.7,129.7,127.8,127.5$, 127.0, 125.1, 124.7, 120.0, 73.7, 66.9, 65.0, 50.3, 49.7, 47.1, 45.6, 27.3, 21.4; ESI(+) MS: $m / z 523.65\left[\mathrm{M}+\mathrm{H}^{+}\right.$; MALDI HRMS: calculated for $\mathrm{C}_{29} \mathrm{H}_{35} \mathrm{~N}_{2} \mathrm{O}_{5} \mathrm{~S}^{+} 523.2261$, found 523.2287.

\subsection{Methylation of 9. Synthesis of 2,3-diaminopropanol 11}

Compound 9 (100.0 mg, $0.18 \mathrm{mmol})$ was methylated with trimethyloxonium tetrafluoroborate ( $66.4 \mathrm{mg}, 0.45 \mathrm{mmol})$, in the presence of DIEA $(0.11 \mathrm{~mL}, 0.63 \mathrm{mmol})$, in DCM $(20 \mathrm{~mL})$, accordingly to the previously published procedure [76]. Pale yellow oil (102.1 mg, quantitative); TLC (diethyl ether $/ n$-hexane 80:20 v/v) $\mathrm{R}_{f}=0.48 ;{ }^{1} \mathrm{H}-\mathrm{NMR}\left(300 \mathrm{MHz}, \mathrm{CDCl}_{3}\right) \delta 8.29-8.44\left(\mathrm{~m}, 2 \mathrm{H}, \mathrm{SO}_{2} \mathrm{ArH}\right), 7.91-8.09$ (m, 2H, SO $\left.\mathrm{SO}_{2} \mathrm{ArH}\right), 7.70-7.80$ (m, 2H, ArH Fmoc), 7.50-7.65 (m, 2H, ArH Fmoc), 7.31-7.42 (m, 2H, ArH Fmoc), 7.23-7.31 (m, 2H, ArH Fmoc), 5.34 (d, 1H, J = 7.1, CHNH), 4.30-4.41 (m, 2H, $\mathrm{CH}_{2}$ Fmoc), 4.12-4.28 (m, 1H, CH Fmoc), 3.75-3.97 (m, 1H, CHNH), 3.60-3.73 (m, 1H, $\left.\mathrm{CH}_{2} \mathrm{O}\right), 3.32-3.48(\mathrm{~m}, 2 \mathrm{H}$, $\mathrm{CH}_{2} \mathrm{O}$ and $\left.\mathrm{CH}_{2} \mathrm{~N}\right), 3.10-3.21\left(\mathrm{~m}, 1 \mathrm{H}, \mathrm{CH}_{2} \mathrm{~N}\right), 2.83\left(\mathrm{~s}, 3 \mathrm{H}, \mathrm{CH}_{3}\right), 1.16\left(\mathrm{~s}, 9 \mathrm{H}, \mathrm{CH}_{3} t \mathrm{Bu}\right) ;{ }^{13} \mathrm{C}-\mathrm{NMR}(75 \mathrm{MHz}$, $\left.\mathrm{CDCl}_{3}\right) \delta 156.1,150.0,143.6,141.2,127.7,127.0,125.0,124.7,124.4,120.0,73.5,66.9,60.5,54.7,51.0,49.1$, 47.1, 35.7, 27.2; $\mathrm{ESI}(+) \mathrm{MS}: \mathrm{m} / z 568.19[\mathrm{M}+\mathrm{H}]^{+}$; MALDI HRMS: calculated for $\mathrm{C}_{29} \mathrm{H}_{34} \mathrm{~N}_{3} \mathrm{O}_{7} \mathrm{~S}^{+} 568.2112$, found 568.2133 . 


\subsection{Synthesis of 2,3-diaminopropanol 12}

To a solution of 10 (100.0 mg, $0.19 \mathrm{mmol})$, in dry DCM (3 mL), TFA (1 mL) and TFE $(0.3 \mathrm{~mL})$ were added. The reaction mixture was magnetically stirred at room temperature for 15 min (TLC: diethyl ether/petroleum ether 80:20, $v / v$ ). After complete conversion of 10, the mixture was evaporated to dryness under reduced pressure conditions. The residue was dissolved in DCM (5 mL), treated with solid $\mathrm{Na}_{2} \mathrm{CO}_{3}$ (CAUTION) until complete gas evolution, and then desalted by elution with small volumes of DCM on a short silica gel pad. The organic solution was dried over $\mathrm{Na}_{2} \mathrm{SO}_{4}$, and evaporated to dryness under reduced pressure conditions, to afford 12 (88.5 mg, quantitative). White solid, mp 142-145 ${ }^{\circ} \mathrm{C}$; TLC (diethyl ether/n-hexane 80:20, v/v): $\mathrm{R}_{f}=0.16 ;{ }^{1} \mathrm{H}-\mathrm{NMR}\left(300 \mathrm{MHz}, \mathrm{CDCl}_{3}\right) \delta$ 7.62-7.80 (m, 4H, ArH Fmoc and ArH Ts), 7.45-7.60 (m, 2H, ArH Fmoc), 7.30-7.40 (m, 2H, ArH Fmoc), 7.19-7.30 (m, 4H, ArH Fmoc and ArH Ts), 5.52-5.73 (m, 1H, NHCO), 5.18 (bs, 1H, NHSO 2 ), 4.00-4.44 (m, 4H, CH Fmoc, $\mathrm{CH}_{2}$ Fmoc and $\left.\mathrm{CHNH}\right), 3.52-3.78\left(\mathrm{~m}, 2 \mathrm{H}, \mathrm{CH}_{2} \mathrm{O}\right), 3.01$ (bs, 1H, OH), $2.50-2.71$ $\left(\mathrm{m}, 2 \mathrm{H}, \mathrm{CH}_{2} \mathrm{NH}\right), 2.32\left(\mathrm{~s}, 3 \mathrm{H}, \mathrm{CH}_{3}\right) ;{ }^{13} \mathrm{C}-\mathrm{NMR}\left(75 \mathrm{MHz} \mathrm{CDCl}_{3}\right) \delta 156.6,143.5,141.2,139.0,136.4$, 129.8, 127.7, 123.1, 126.3, 125.1, 119.9, 67.0, 62.9, 53.4, 47.0, 43.2, 21.4; MALDI HRMS: calculated for $\mathrm{C}_{25} \mathrm{H}_{27} \mathrm{~N}_{2} \mathrm{O}_{5} \mathrm{~S}^{+} 467.1635$, found 467.1659 .

\subsection{Preparation of Fmoc-L-Dap(Ts)-OCH $\mathrm{OCH}_{3}$ (14)}

Compound 12 (232.8 mg, $0.5 \mathrm{mmol})$ was dissolved in acetone $(5 \mathrm{~mL})$, and aqueous $15 \%$ solution of $\mathrm{NaHCO}_{3}(3 \mathrm{~mL})$ was added, followed by solid $\mathrm{NaBr}(10.2 \mathrm{mg}, 0.1 \mathrm{mmol})$. TEMPO $(7.5 \mathrm{mg}, 0.05 \mathrm{mmol})$ was added to the mixture, under magnetic stirring at $0{ }^{\circ} \mathrm{C}$. After slow addition of TCCA $(220.5 \mathrm{mg}$, $5.0 \mathrm{mmol}$ ) within $20 \mathrm{~min}$ at $0^{\circ} \mathrm{C}$, the mixture was maintained under magnetic stirring overnight at room temperature. Then, 2-propanol $(3 \mathrm{~mL})$ was added, and the mixture was filtered on a short pad of Celite $545^{\circledR}$, concentrated under vacuum, and treated with $5 \mathrm{~mL}$ of a saturated aqueous solution of $\mathrm{Na}_{2} \mathrm{CO}_{3}$. The aqueous phase was washed with small portions of AcOEt $(3 \times 10 \mathrm{~mL})$, treated with $5 \%$ aqueous $\mathrm{KHSO}_{4}(10 \mathrm{~mL})$, and re-extracted with AcOEt $(3 \times 10 \mathrm{~mL})$. The organic layers were dried over $\mathrm{MgSO}_{4}$ and paper-filtered, and the solvent was evaporated to dryness, yielding a raw material which was directly treated with an excess of diazomethane ( $0.66 \mathrm{~N}$ solution in dry DCM, $4 \mathrm{~mL})$, under magnetic stirring for $15 \mathrm{~min}$ at room temperature [85]. The mixture was evaporated to dryness under reduced pressure conditions (CAUTION: use a fume hood), to give 14. White solid (227.2 $\mathrm{mg} ; 92 \%$, over 2 steps; $68 \%$ total yield, based on the initial amount of the amino acid 1, $1.30 \mathrm{mmol}) ; \mathrm{mp}>90{ }^{\circ} \mathrm{C}$, dec.; TLC (diethyl ether/ $n$-hexane 80:20, v/v) $\mathrm{R}_{f}=0.36 ;{ }^{1} \mathrm{H}-\mathrm{NMR}\left(300 \mathrm{MHz}, \mathrm{CDCl}_{3}\right) \delta 7.65-7.79(\mathrm{~m}, 4 \mathrm{H}$, Ar Fmoc and ArH Ts), 7.52-7.61 (m, 2H, ArH Fmoc), 7.35-7.43 (m, 2H, ArH Fmoc), 7.22-7.34 (m, 5H, Ar Fmoc, ArH Ts and $\left.\mathrm{NHSO}_{2}\right), 5.89$ (d, 1H, J = 6.5 Hz, NHCO), 4.48-4.62 (m, 4H, CH Fmoc, $\mathrm{CH}_{2} \mathrm{Fmoc}$ and $\mathrm{CHNH}), 3.95\left(\mathrm{dt}, 1 \mathrm{H}, J=21\right.$ and $\left.11 \mathrm{~Hz}, \mathrm{CH}_{2} \mathrm{~N}\right), 3.94\left(\mathrm{dt}, 1 \mathrm{H}, J=21\right.$ and $\left.11 \mathrm{~Hz}, \mathrm{CH}_{2} \mathrm{~N}\right), 3.77(\mathrm{~s}$, $\left.3 \mathrm{H}, \mathrm{OCH}_{3}\right), 2.38\left(\mathrm{~s}, 3 \mathrm{H}, \mathrm{CH}_{3}\right) ;{ }^{13} \mathrm{C}-\mathrm{NMR}\left(75 \mathrm{MHz}, \mathrm{CDCl}_{3}\right) \delta 171.1,156.8,143.6,141.3,123.7,129.6$, 128.6, 127.7, 127.0, 126.4, 125.0, 119.9, 67.1, 56.0, 52.7, 47.1, 41.8, 22.1; MALDI HRMS: calculated for $\mathrm{C}_{26} \mathrm{H}_{27} \mathrm{~N}_{2} \mathrm{O}_{6} \mathrm{~S}^{+} 495.1584$, found 495.1606 .

\subsection{Synthesis of Boc-L-Dap(Fmoc)-OH (20): Multistep Procedure}

Step 1: Acidolysis. To a solution of 4 (229 mg, $0.5 \mathrm{mmol})$, in dry DCM (3 mL), TFA (2 mL) and TFE $(0.3 \mathrm{~mL})$ were added. The reaction mixture was magnetically stirred at room temperature for $15 \mathrm{~min}$ (TLC: diethyl ether/petroleum ether 80:20, v/v). After complete conversion of 4, the mixture was evaporated to dryness under reduced pressure conditions. The residue was dissolved in DCM (5 mL), treated with solid $\mathrm{Na}_{2} \mathrm{CO}_{3}$ until complete gas evolution, and desalted on a short pad of Celite $545^{\circledR}$ by elution with small volumes of DCM. The organic phase was dried over $\mathrm{Na}_{2} \mathrm{SO}_{4}$ and evaporated to dryness under reduced pressure conditions, to afford a crude solid which was directly used in the next step, without purification. Step 2: Oxidation. The crude material obtained from the previous step was subjected to oxidation, applying the procedure above described for the preparation of the methyl ester 14. The final crude product was dried under vacuum, and then subjected to the next 
step without further purification. Step 3: Removal of Fmoc group. The crude product recovered from step 2, was reacted with $5 \mathrm{~mL}$ of a 20\% DEA solution in DCM, under magnetic stirring at room temperature for $30 \mathrm{~min}$. Evaporation to dryness of volatile gave a solid residue that was dissolved in AcOEt and precipitated with cold n-pentane. The solid was filtered, washed three times with small portions of n-pentane, and dried under vacuum. The crude material, as recovered, was immediately subjected to the next step of the procedure. Step 4: Protection with Boc group. The crude solid recovered from step 3 was suspended in $\mathrm{H}_{2} \mathrm{O}(5 \mathrm{~mL})$, containing $\mathrm{NaHCO}_{3}$ (two equivalents with respect to $4 ; 88 \mathrm{mg}, 1 \mathrm{mmol}$ ), and a solution of di-tert-butyl-dicarbonate (1.1 equivalents with respect to 4; $120 \mathrm{mg}, 0.55 \mathrm{mmol})$ in 1,4-dioxane $(5 \mathrm{~mL})$ was added dropwise to the reaction system. The resulting clear mixture was maintained under stirring overnight at room temperature, and then concentrated under reduced pressure conditions to give an aqueous residue which was made acidic by adding $5 \%$ aqueous $\mathrm{KHSO}_{4}$, before being extracted with ethyl acetate $(3 \times 10 \mathrm{~mL})$. The organic layers were collected, washed once with brine $(10 \mathrm{~mL})$, dried over $\mathrm{Na}_{2} \mathrm{SO}_{4}$, paper-filtered, and evaporated to dryness to give a white solid which was transformed in a white powder by co-evaporation from a

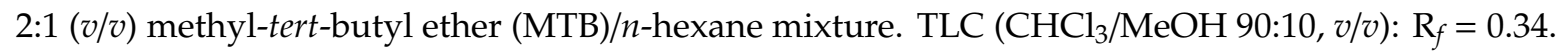
Step 5: Hydrogenolysis of benzyl group. The crude product recovered from step 4 was dissolved in absolute ethanol $(5 \mathrm{~mL})$, and the reaction flask was immersed in a water bath at $25{ }^{\circ} \mathrm{C}$. To the alcoholic solution, $10 \%$ palladium-carbon $(22.9 \mathrm{mg})$ and 1,4-cyclohexadiene (10 equivalents with respect to 4; $0.47 \mathrm{~mL}, 5.0 \mathrm{mmol}$ ) were added, and the mixture was allowed to react under magnetic stirring overnight. After filtration over a short pad of Celite $545^{\circledR}$, the solvent was evaporated under reduced pressure conditions, and the solid residue was partitioned in a 1:1 (v/v) $\mathrm{H}_{2} \mathrm{O} /$ EtOAc mixture $(10 \mathrm{~mL})$. The aqueous phase was separated, back extracted with EtOAc $(3 \times 10 \mathrm{~mL})$, concentrated under reduced pressure conditions, and lyophilized. Step 6: Protection with Fmoc group. The crude product obtained from step 5 was dissolved in a 1:1 (v/v) 1,4-dioxane/ $\mathrm{H}_{2} \mathrm{O}$ mixture $\left(15 \mathrm{~mL}\right.$ ) containing $\mathrm{NaHCO}_{3}$ (two equivalents with respect to $4 ; 88 \mathrm{mg}, 1 \mathrm{mmol}$ ). A solution of Fmoc-OSu (1.1 equivalents with respect to $4 ; 185.5 \mathrm{mg}, 25 \mathrm{mmol})$ in 1,4-dioxane (5 mL) was added dropwise in $35 \mathrm{~min}$, and the resulting mixture was magnetically stirred overnight at room temperature. The reaction was checked by TLC $\left(\mathrm{CHCl}_{3} / \mathrm{MeOH} 95: 5, v / v\right.$; ninhydrin as the visualizing agent), and, after complete disappearing of the free amino compound, the solution was concentrated under vacuum, and the aqueous residue was made acidic $(\mathrm{pH}=2.5)$ by adding $5 \%$ aqueous $\mathrm{KHSO}_{4}$ and extracted with ethyl acetate $(3 \times 10 \mathrm{~mL})$. The collected organic layers were washed once with brine $(10 \mathrm{~mL})$, dried over $\mathrm{Na}_{2} \mathrm{SO}_{4}$, paper=filtered, and evaporated to dryness to give a viscous residue which was rapidly dissolved in the smallest volume of DCM and precipitated from cold $n$-pentane. The precipitate was filtered under vacuum and dried by using an oil pump. The final product was purified by column chromatography. White powder ( $404.7 \mathrm{mg} ; 93 \%$ over six steps; $73 \%$ based on the initial amount of $1,1.30 \mathrm{mmol}$ ); $\mathrm{mp}>78{ }^{\circ} \mathrm{C}$ (dec.); TLC $\left(\mathrm{CHCl}_{3} / \mathrm{MeOH} 90: 10, v / v\right): \mathrm{R}_{f}=0.35 ;[\alpha]_{D}^{20}=-11.8$ (c 1.0, $\left.\mathrm{CH}_{3} \mathrm{OH}\right) ;{ }^{1} \mathrm{H}-\mathrm{NMR}(300 \mathrm{MHz}$, $\left.\mathrm{CDCl}_{3}\right) \delta 7.74(\mathrm{~d}, 2 \mathrm{H}, J=6.2 \mathrm{~Hz}, \operatorname{ArH~Fmoc}), 7.56(\mathrm{~d}, 2 \mathrm{H}, J=6.2 \mathrm{~Hz}, \operatorname{ArH~Fmoc}), 7.36(\mathrm{t}, 2 \mathrm{H}, J=6.2 \mathrm{~Hz}$, ArH Fmoc), 7.29 (t, 2H, J = 6.2 Hz, ArH Fmoc), 5.71 (bs, 1H, NHCO), 5.40 (bs, 1H, NHCO), 4.41 (d, $2 \mathrm{H}$, $\left.J=6.1 \mathrm{~Hz}, \mathrm{CH}_{2} \mathrm{Fmoc}\right), 4.24-4.36(\mathrm{~m}, 1 \mathrm{H}, \mathrm{CHNH}), 4.19(\mathrm{t}, 1 \mathrm{H}, J=6.1 \mathrm{~Hz}), 3.51-3.72\left(\mathrm{~m}, 2 \mathrm{H}, \mathrm{CH}_{2} \mathrm{NH}\right)$, 1.45 (s, 9H, $t \mathrm{Bu}) ;{ }^{13} \mathrm{C}-\mathrm{NMR}\left(75 \mathrm{MHz}, \mathrm{CDCl}_{3}\right) \delta 172.3,157.6,157.1,143.8,141.4,127.8,127.1,125.0,120.0$, 67.5, 54.8, 47.2, 42.7, 34.0, 28.1. MALDI HRMS: calculated for $\mathrm{C}_{23} \mathrm{H}_{27} \mathrm{~N}_{2} \mathrm{O}_{6}{ }^{+} 427.1864$, found 427.1881.

\subsection{Methylation of 20. Synthesis of Fmoc-L-Dap(Boc)-OCH $\mathrm{OH}_{3}$ (21)}

The purified amino acid 20 (404.7 $\mathrm{mg}, 0.95 \mathrm{mmol})$ was treated with an excess of a $0.66 \mathrm{~N}$ solution of diazomethane in dry DCM $(5 \mathrm{~mL})$, under magnetic stirring, for $15 \mathrm{~min}$ at room temperature. The mixture was evaporated to dryness under reduced pressure conditions (CAUTION: use a fume hood), and the solid residue was co-evaporated twice from small portions of a 2:1 (v/v) MTB/n-pentane mixture, to give pure 21 without need for chromatography. White powder $(417.8 \mathrm{mg}$, quantitative); $\mathrm{mp}>83{ }^{\circ} \mathrm{C}$ (dec.); $\mathrm{TLC}\left(\mathrm{CHCl}_{3} / \mathrm{MeOH} 90: 10, v / v\right): \mathrm{R}_{f}=0.65$. $[\alpha]_{D}^{20}=-12.5$ (c 1.0, $\mathrm{CH}_{3} \mathrm{OH}$; Lit. [51]: -10 and $-14 ;{ }^{1} \mathrm{H}-\mathrm{NMR}\left(300 \mathrm{MHz}, \mathrm{CDCl}_{3}\right) \delta 7.76(\mathrm{~d}, 2 \mathrm{H}, J=6.2 \mathrm{~Hz}, \operatorname{ArH~Fmoc}), 7.57(\mathrm{~d}, 2 \mathrm{H}, J=6.2 \mathrm{~Hz}$, 
ArH Fmoc), 7.39 (t, 2H, J = 6.2 Hz, ArH Fmoc), 7.28 (t, 2H, $J=6.2 \mathrm{~Hz}$, ArH Fmoc), 5.32 (bs, 1H, NHCO), 5.11 (bs, 1H, NHCO), 5.40 (bs, 1H, NHCO), 4.30-4.42 (m, 3H, CHNH and $\mathrm{CH}_{2}$ Fmoc), $4.21(\mathrm{t}, 1 \mathrm{H}, J=$ $6.1 \mathrm{~Hz}, \mathrm{CH}$ Fmoc), 3.75 (s, 3H, OCH 3$), 3.50-3.63\left(\mathrm{~m}, 2 \mathrm{H}, \mathrm{CH}_{2} \mathrm{NH}\right), 1.45(\mathrm{~s}, 9 \mathrm{H}, t \mathrm{Bu}) ;{ }^{13} \mathrm{C}-\mathrm{NMR}(75 \mathrm{MHz}$, $\left.\mathrm{CDCl}_{3}\right) \delta 171.0,156.7,155.4,143.9,141.4,127.7,127.1,125.0,120.0,80.4,67.1,54.2,52.6,47.3,43.2,28.3$; MALDI HRMS: calculated for $\mathrm{C}_{24} \mathrm{H}_{29} \mathrm{~N}_{2} \mathrm{O}_{6}{ }^{+} 441.2020$, found 441.1998.

\subsection{Coupling of $\mathbf{2 1}$ with Fmoc-L-Ala-OH and Fmoc-D-Ala-OH. Synthesis of diastereomers 23 and 24}

DEA (2 mL) was added to a solution of 21 (356.4 mg, $0.81 \mathrm{mmol})$, in dry DCM (5 mL), under magnetic stirring at room temperature. After $30 \mathrm{~min}$, the volatile was removed under reduced pressure conditions, to afford a solid residue which was dissolved in the minimum volume of EtOAc and precipitated from cold $n$-pentane. The supernatant was separated, and the solid residue was washed with small portions of cold $n$-pentane $(5 \times 5 \mathrm{~mL})$, then dried under vacuum. The recovered crude product 22 was dissolved in DCM $(3 \mathrm{~mL})$ and added to a magnetically stirred mixture of DIEA (0.35 mL; $2.03 \mathrm{mmol})$, HOBt monohydrate (150 mg; $0.97 \mathrm{mmol})$, and EDC (160 mg; $0.85 \mathrm{mmol})$ in DCM (5 mL). After $15 \mathrm{~min}$ at room temperature, the appropriate enantiomer of Fmoc-Ala-OH (311.3 mg; $1.0 \mathrm{mmol})$, dissolved in DCM (3 mL), was added dropwise, and the mixture was allowed to stir overnight at room temperature. The solvent was then evaporated to dryness under reduced pressure conditions, and the residue was solubilized in EtOAc $(10 \mathrm{~mL})$, washed once with $5 \%$ aqueous $\mathrm{NaHCO}_{3}(5 \mathrm{~mL})$, once with $5 \%$ aqueous $\mathrm{KHSO}_{4}(5 \mathrm{~mL})$, and once with brine $(5 \mathrm{~mL})$. The organic layer was dried over $\mathrm{Na}_{2} \mathrm{SO}_{4}$, paper-filtered, and evaporated to dryness to yield the expected dipeptides 23 and 24, both as a white powder. The pair of crude diastereomers was directly analyzed by RP U-HPLC/MS, without further pre-injection purification (Supplementary Materials).

\section{Conclusions}

In summary, a synthetic route is proposed for the multi-step preparation of orthogonal di-protected L-Dap methyl esters. In the proposed procedure, commercial $N^{\alpha}$-Fmoc-O-tert-butyl-D-serine is initially transformed into the corresponding serinal. This compound is subjected to a Ti(IV)-assisted reductive amination with amines and arylsulfonamides, to give 2,3-diaminopropanols which are in turn oxidized by the TCCA/TEMPO system. The obtained carboxylic acids are finally methylated, to yield the targeted esters in $68 \%-73 \%$ overall yields. Reductive amination allows also the preparation of $N$-methylated and $N$-ethylated 2,3-diaminopropanol intermediates as the most likely precursors of $N$-alkylated L-Dap scaffolds. Chromatographic purifications are minimized through the entire procedure. The total preservation of chirality enhanced the synthetic utility of the method, which can successfully be used to prepare protected L-Dap building blocks for a broad application in the synthesis of biologically active peptides.

Supplementary Materials: The following are available online at http://www.mdpi.com/1420-3049/25/6/1313/s1: Figure S1: ${ }^{1} \mathrm{H}$ spectrum of 2; Figure S2: ${ }^{13} \mathrm{C}$ spectrum of 2; Figure S3: ${ }^{1} \mathrm{H}$ spectrum of 3; Figure S4: ${ }^{13} \mathrm{C}$ spectrum of 3; Figure S5: ${ }^{1} \mathrm{H}$ spectrum of 4; Figure S6: ${ }^{13} \mathrm{C}$ spectrum of 4; Figure S7: ${ }^{1} \mathrm{H}$ spectrum of 5; Figure S8: ${ }^{13} \mathrm{C}$ spectrum of 5; Figure S9: ${ }^{1} \mathrm{H}$ spectrum of 6; Figure S10: ${ }^{13} \mathrm{C}$ spectrum of 6; Figure S11: ${ }^{1} \mathrm{H}$ spectrum of 7; Figure S12: ${ }^{13} \mathrm{C}$ spectrum of 7; Figure S13: ${ }^{1} \mathrm{H}$ spectrum of 8; Figure S14: ${ }^{13} \mathrm{C}$ spectrum of 8; Figure S15: ${ }^{1} \mathrm{H}$ spectrum of 9; Figure S16: ${ }^{13} \mathrm{C}$ spectrum of 9; Figure S17: ${ }^{1} \mathrm{H}$ spectrum of 10; Figure S18: ${ }^{13} \mathrm{C}$ spectrum of 10; Figure S19: ${ }^{1} \mathrm{H}$ spectrum of 11; Figure S20: ${ }^{13} \mathrm{C}$ spectrum of 11; Figure S21: ${ }^{1} \mathrm{H}$ spectrum of 12; Figure S22: ${ }^{13} \mathrm{C}$ spectrum of 12; Figure S23: ${ }^{1} \mathrm{H}$ spectrum of 13; Figure S24: ${ }^{13} \mathrm{C}$ spectrum of 13; Figure S25: ${ }^{1} \mathrm{H}$ spectrum of 20; Figure S26: ${ }^{13} \mathrm{C}$ spectrum of 20; Figure S27: ${ }^{1} \mathrm{H}$ spectrum of 21; Figure S28: ${ }^{13} \mathrm{C}$ spectrum of 21; Figures S29-S36: ESI(+) MS spectra of 4-11; Figure S37: RP U-HPLC analysis of crude 23 and crude 24; Figures S38 and S39: ESI(+) MS spectra of 23 and 24.

Author Contributions: Conceptualization, C.S., C.M.A., and A.T.; methodology, C.S., A.T., C.M.A., and P.D.L.; software, C.S.; NMR analysis, C.S.; MS analysis, D.A.; RP U-HPLC/MS analysis, F.M.; polarimetry, P.D.L.; investigation, C.S.; data curation, C.S., A.T.; writing-original draft preparation, C.S. and A.T.; writing-review and editing, C.S. and C.M.A.; supervision, C.S. All authors have read and agreed to the published version of the manuscript.

Funding: This research received no external funding. 
Acknowledgments: Support from MIUR (Ministero dell'istruzione, dell'Università e della Ricerca, Italy) is gratefully acknowledged. This work is dedicated to the memory of Prof. Giovanni Sindona.

Conflicts of Interest: The authors declare no conflict of interest. MIUR (Ministero Italiano dell'Università e della Ricerca) had no role in the design of the study; in the collection, analyses, or interpretation of data; in the writing of the manuscript, or in the decision to publish the results.

\section{Abbreviations}

TEMPO (2:2,6,6-tetramethylpiperidin-1-yl)oxyl, TCCA (trichloroisocyanuric acid); DEA ( $N, N$-diethylamine), DIEA ( $N, N$-diisopropylethylamine); HOBt (1-hydroxybenzotriazole); DIC ( $N, N^{\prime}$-diisopropylcarbodiimide); EDC (1-(3-dimethylaminopropyl)-3-ethylcarbodiimide hydrochloride); $\mathrm{Boc}_{2} \mathrm{O}$ (di-tert-butyl-dicarbonate); Fmoc-OSu (N-(9-fluorenylmethoxycarbonyloxy)succinimide); TFA (trifluoroacetic acid); TFE (trifluoroethanol); THF (tetrahydrofuran); DCM (dichloromethane); AcOEt (ethyl acetate); $\mathrm{CH}_{3} \mathrm{CN}$ (acetonitrile); MTB (methyltert-butyl ether); TLC (thin-layer chromatography); FCC (flash column chromatography); RP U-HPLC/MS (reversed-phase ultrafast high-pressure liquid chromatography/mass spectrometry); HRMS (high-resolution mass spectrometry); ESI(+) MS (positive-mode electro spray ionization mass spectrometry); TOF (time of flight); MS/MS (tandem mass spectrometry); TOCSY (total correlation spectroscopy).

\section{References}

1. Xu, Z.; Sun, Z.; Li, S.; Xu, Z.; Cao, C.; Xu, Z.; Feng, X.; Xu, H. Systematic unravelling of the biosynthesis of poly (L-diaminopropionic acid) in Streptomyces albulus PD-1. Sci. Rep. 2015, 5, 17400. [CrossRef]

2. Dobrovinskaya, N.A.; Archer, I.; Hulme, A.N. Chemoenzymatic and chemical routes to the non-proteinaceous amino acid Albizziine and its amide derivative. Synlett 2008, 4, 513-516.

3. Kjaer, A.; Olesen Larsen, P. Amino acid studies. Part II. Structure and synthesis of Albizziine (L-2-amino-3-ureidopropionic acid), an amino acid from higher plants. Acta Chem. Scand. 1959, 13, 1565-1574. [CrossRef]

4. Otsuka, M.; Kittaka, A.; Iimori, T.; Yamashita, H.; Kobayashi, S.; Ohno, M. Synthetic studies on an antitumor antibiotic, Bleomycin. XII. Preparation of an L-2,3-diaminopropionic acid derivative as a synthetic intermediate. Chem. Pharm. Bull. 1985, 33, 509-514. [CrossRef] [PubMed]

5. Oshitari, T.; Shibasaki, M.; Yoshizawa, T.; Tomita, M.; Takao, K.; Kobayashi, S. Synthesis of 2-O-(3-O-carbamoyl- $\alpha$-D-mannopyranosyl)-L-gulopyranose: Sugar moiety of antitumor antibiotic Bleomycin. Tetrahedron 1997, 53, 10993-11006. [CrossRef]

6. Highfield, J.A.; Mehta, L.K.; Parrick, J.; Wardman, P. Synthesis, hydroxyl radical production and cytotoxicity of analogues of Bleomycin. Bioorg. Med. Chem. 2000, 8, 1065-1073. [CrossRef]

7. Sugiyama, M.; Kumagai, T. Molecular and structural biology of Bleomycin and its resistance determinants. J. Biosci. Bioeng. 2002, 93, 105-116. [CrossRef]

8. Xu, Z.-D.; Wang, M.; Xiao, S.-L.; Liu, C.-L.; Yang, M. Synthesis, biological evaluation and DNA binding properties of novel Bleomycin analogues. Bioorg. Med. Chem. Lett. 2003, 13, 2595-2599. [CrossRef]

9. Schmidt, U.; Mundinger, K.; Mangold, R.; Lieberknecht, A. Lavendomycin: Total synthesis and assignment of configuration. J. Chem. Soc. Chem. Commun. 1990, 18, 1216-1219. [CrossRef]

10. Wang, M.; Gould, S.J. Biosynthesis of Capreomycin. 2. Incorporation of L-serine, L-alanine, and L-2,3-diaminopropionic acid. J. Org. Chem. 1993, 58, 5176-5180. [CrossRef]

11. Bastiaans, H.M.M.; van der Baan, J.L.; Ottenheijm, H.C.J. Flexible and convergent total synthesis of cyclotheonamide B. J. Org. Chem. 1997, 62, 3880-3889. [CrossRef]

12. Gopalsamy, A.; Yang, H.; Ellingboe, J.W.; Kees, K.L.; Yoon, J.; Murrills, R. Parallel solid-phase synthesis of Vitronectin receptor ( $\alpha \mathrm{v} \beta 3$ ) inhibitors. Bioorg. Med. Chem. Lett. 2000, 10, 1715-1718. [CrossRef]

13. Stokowa-Sołtys, K.; Dzyhovskyi, V.; Wieczorek, R.; Jeżowska-Bojczuk, M. Phleomycin complex-Coordination mode and in vitro cleavage of DNA. J. Inorg. Biochem. 2019, 195, 71-82. [CrossRef] [PubMed]

14. Noden, M.; Moreira, R.; Huang, E.; Yousef, A.; Palmer, M.; Taylor, S.D. Total synthesis of Paenibacterin and its analogues. J. Org. Chem. 2019, 84, 5339-5347. [CrossRef] [PubMed]

15. Mant, C.T.; Jiang, Z.; Gera, L.; Davis, T.; Nelson, K.L.; Bevers, S.; Hodges, R.S. De novo designed amphipathic $\alpha$-helical antimicrobial peptides incorporating Dab and Dap residues on the polar face to treat the Gram-negative pathogen, Acinetobacter baumannii. J. Med. Chem. 2019, 62, 3354-3366. [CrossRef] [PubMed] 
16. Smith, C.J.; Sieckman, G.L.; Owen, N.K.; Hayes, D.L.; Mazuru, D.G.; Kannan, R.; Volkert, W.A.; Hoffman, T.J. Radiochemical investigations of Gastrin-releasing Peptide Receptor-specific [99mTc $(X)(C O)_{3}$-Dpr-SerSer-Ser-Gln- Trp-Ala-Val-Gly- His-Leu-Met- $\left(\mathrm{NH}_{2}\right)$ ] in PC-3, tumor-bearing, rodent models: Syntheses, radiolabeling, and in vitro/in vivo studies where $\mathrm{Dpr}=2,3$-Diaminopropionic acid and $\mathrm{X}=\mathrm{H}_{2} \mathrm{O}$ or $\mathrm{P}\left(\mathrm{CH}_{2} \mathrm{OH}\right)_{3}$. Cancer Res. 2003, 63, 4082-4088.

17. Audic, N.; Potier, G.; Sasaki, N.A. New 2,3-diaminopropionic acid inhibitors of AGE and ALE formation. Org. Biomol. Chem. 2013, 11, 773-780. [CrossRef]

18. Fujisawa, T.; Katakura, S.-I.; Odake, S.; Morita, Y.; Yasuda, J.; Yasumatsu, I.; Morikawa, T. Design and synthesis of carboxylate inhibitors for matrix metalloproteinases. Chem. Pharm. Bull. 2001, 49, 1272-1279. [CrossRef]

19. Beasley, F.C.; Cheung, J.; Heinrichs, D.E. Mutation of L-2,3-diaminopropionic acid synthase genes blocks staphyloferrin B synthesis in Staphylococcus aureus. BMC Microbiol. 2011, 11, 1-12. [CrossRef]

20. Kobylarz, M.J.; Grigg, J.C.; Takayama, S.-I.J.; Rai, D.K.; Heinrichs, D.E.; Murphy, M.E.P. Synthesis of L-2,3-diaminopropionic acid, a siderophore and antibiotic precursor. Chem. Biol. 2014, 21, 379-388. [CrossRef]

21. Liu, Y.; Oliveira, B.L.; Correia, J.D.G.; Santos, I.C.; Santos, I.; Spingler, B.; Alberto, R. Syntheses of bifunctional 2,3-diamino propionic acid-based chelators as small and strong tripod ligands for the labelling of biomolecules with 99mTc. Org. Biomol. Chem. 2010, 8, 2829-2839. [CrossRef]

22. Sengupta, S.; Krishnan, M.A.; Dudhe, P.; Reddy, R.B.; Giri, B.; Chattopadhyay, S.; Chelvam, V. Novel solid-phase strategy for the synthesis of ligand-targeted fluorescent-labelled chelating peptide conjugates as a theranostic tool for cancer. Beilstein J. Org. Chem. 2018, 14, 2665-2679. [CrossRef] [PubMed]

23. Szyrwiel, Ł.; Shimura, M.; Setner, B.; Szewczuk, Z.; Malec, K.; Malinka, W.; Brasun, J.; Pap, J.S. SOD-Like activity of copper(II) containing metallopeptides branched by 2,3-diaminopropionic acid: What the N-termini elevate, the C-terminus ruins. Int. J. Pept. Res. Ther. 2019, 25, 711-717. [CrossRef]

24. Batoon, P.; Oomens, J.; Berden, G.; Ren, J. Conformations of protonated AlaDap and DapAla characterized by IRMPD spectroscopy and molecular modeling. J. Phys. Chem. B 2018, 122, 2191-2202. [CrossRef] [PubMed]

25. Xue, C.-B.; Roderick, J.; Jackson, S.; Rafalski, M.; Rockwell, A.; Mousa, S.; Olson, R.E.; DeGrado, W.F. Design, synthesis, and in vitro activities of benzamide-core glycoprotein IIb/IIIa antagonists: 2,3-diaminopropionic acid derivatives as surrogates of aspartic acid. Bioorg. Med. Chem. 1997, 5, 693-705. [CrossRef]

26. Quan, K.; Li, G.; Tao, L.; Xie, Q.; Yuan, Q.; Wang, X. Diaminopropionic acid reinforced graphene sponge and its use for hemostasis. ACS Appl. Mater. Interfaces 2016, 8, 7666-7673. [CrossRef] [PubMed]

27. Minematsu, Y.; Kang, S.; Waki, M.; Kato, T.; Izumiya, N. Synthesis of derivatives on $N^{2}$-acetyl$N^{3}$-glycyl-L-2,3-diaminopropionic acid and their hydrolyses by trypsin. Bull. Chem. Soc. Jpn. 1981, 54, 297-298. [CrossRef]

28. Huguenin-Dezot, N.; Alonzo, D.A.; Heberlig, G.W.; Mahesh, M.; Nguyen, D.P.; Dornan, M.H.; Boddy, C.N.; Schmeing, T.M.; Chin, J.W. Trapping biosynthetic acyl-enzyme intermediates with encoded 2,3-diaminopropionic acid. Nature 2019, 565, 112-117. [CrossRef]

29. Maillard, N.; Darbre, T.; Reymond, J.-L. Identification of catalytic peptide dendrimers by "off-bead" in silica high-throughput screening of combinatorial libraries. J. Comb. Chem. 2009, 11, 667-675. [CrossRef]

30. Featherston, A.L.; Shugrue, C.R.; Mercado, B.Q.; Miller, S.J. Phosphothreonine (pThr)-based multifunctional peptide catalysis for asymmetric Baeyer-Villiger oxidations of cyclobutanones. ACS Catal. 2019, 9, 242-252. [CrossRef]

31. Abbate, V.; Liang, W.; Patel, J.; Lan, Y.; Capriotti, L.; Iacobucci, V.; Bui, T.T.; Chaudhuri, P.; Kudsiova, L.; Vermeer, L.S.; et al. Manipulating the $\mathrm{pH}$ response of 2,3-diaminopropionic acid rich peptides to mediate highly effective gene silencing with low-toxicity. J. Control. Release 2013, 172, 929-938. [CrossRef] [PubMed]

32. Roviello, G.N.; Musumeci, D.; Bucci, E.M.; Pedone, C. Synthesis of a diaminopropanoic acid-based nucleoamino acid and assembly of cationic nucleopeptides for biomedical applications. Amino Acids 2012, 43, 2537-2543. [CrossRef] [PubMed]

33. Meierhenrich, U.J.; Muñoz Caro, G.M.; Bredehöft, J.H.; Jessberger, E.K.; Thiemann, W.H.P. Identification of diamino acids in the Murchison meteorite. Proc. Natl. Acad. Sci. USA 2004, 101, 9182-9186. [CrossRef] [PubMed]

34. Frenkel-Pintera, M.; Haynesa, J.W.; Ca, M.; Petrova, A.S.; Burcara, B.T.; Krishnamurthya, R.; Huda, N.V.; Lemana, L.J.; Williams, L.D. Selective incorporation of proteinaceous over nonproteinaceous cationic amino 
acids in model prebiotic oligomerization reactions. Proc. Natl. Acad. Sci. USA 2019, 116, 16338-16346. [CrossRef]

35. Nadir, U.K.; Vijaya Krishna, R.; Singh, A. A new and facile route for the synthesis of chiral 1,2-diamines and 2,3-diamino acids. Tetrahedron Lett. 2005, 46, 479-482. [CrossRef]

36. Kucharczyk, N.; Badet, B.; Le Goffic, F. Quantitative synthesis of $L$ or $D N^{2}$-tert-butoxycarbonyl2,3-diaminopropanoic acid from protected L or D-serine- $\beta$-lactone. Synth. Commun. 1989, 19, 1603-1609. [CrossRef]

37. Stanley, M.S. Orthogonally protected N3-(carboxymethyl)-L-2,3-diaminopropanoic acids and O-(carboxymethyl)-L-serines on solid-phase peptide synthesis. J. Org. Chem. 1992, 57, 6421-6430. [CrossRef]

38. Couturier, C.; Blanchet, J.; Schlama, T.; Zhu, J. Aziridinium from N,N-dibenzyl serine methyl ester: Synthesis of enantiomerically pure $\beta$-amino and $\alpha, \beta$-diamino esters. Org. Lett. 2006, 8, 2183-2186. [CrossRef] [PubMed]

39. Benoiton, L. Conversion of p-chloro-L-alanine to $\alpha$-carbobenzoxy-DL-diaminopropionic acid. Can. J. Chem. 1968, 46, 1449-1552. [CrossRef]

40. Lucet, D.; Le Gall, T.; Mioskowski, C. The chemistry of vicinal diamines. Angew. Chem. Int. Ed. 1998, 37, 2580-2627. [CrossRef]

41. Davoli, P.; Forni, A.; Moretti, I.; Prati, F. Stereochemistry of nucleophilic ring-opening reactions of optically active N-acetyl-2-methoxycarbonylaziridine. Tetrahedron Asymmetry 1995, 6, 2011-2016. [CrossRef]

42. Luo, Y.; Blaskovich, M.A.; Lajoie, G.A. Stereoselective synthesis of $\alpha$-substituted $\alpha$, $\beta$-diamino acids from $\alpha$-hydroxy amino acids. J. Org. Chem. 1999, 64, 6106-6111. [CrossRef]

43. Kretsinger, J.K.; Schneider, J.P. Design and application of basic amino acids displaying enhanced hydrophobicity. J. Am. Chem. Soc. 2003, 125, 7907-7913. [CrossRef]

44. Carrasco, M.R.; Brown, R.T.; Doan, V.H.; Kandel, S.M.; Lee, F.C. 2-(N-Fmoc)-3-(N-Boc- $N$-methoxy)diaminopropanoic acid, an amino acid for the synthesis of mimics of $O$-linked glycopeptides. Biopolymers 2006, 84, 414-420. [CrossRef] [PubMed]

45. Rao, R.V.R.; Tantry, S.J.; Suresh Babu, V.V. Practical and efficient synthesis of orthogonally protected $\alpha$-2,3-diaminopropionic acid (2,3-Dap), 2,4-diaminobutanoic acid (2,4-Dab), and their N-methylated derivatives. Synth. Commun. 2006, 36, 2901-2912. [CrossRef]

46. Barghash, R.F.; Massi, A.; Dondoni, A. Synthesis of thiourea-tethered C-glycosyl amino acids via isothiocyanate-amine coupling. Org. Biomol. Chem. 2009, 7, 3319-3330. [CrossRef]

47. Banerjee, S.; Wiggins, W.J.; Geoghegan, J.L.; Anthony, C.T.; Woltering, E.A.; Masterson, D.S. Novel synthesis of various orthogonally protected $C \alpha$-methyllysine analogues and biological evaluation of a vapreotide analogue containing (S)- $\alpha$-methyllysine. Org. Biomol. Chem. 2013, 11, 6307-6319. [CrossRef]

48. Lindahl, F.; Hoang, H.N.; Fairlie, D.P.; Cooper, M.A. Facile synthesis of mono- and bis-methylated Fmoc-Dap, -Dab and -Orn amino acids. Chem. Commun. 2015, 51, 4496-4498. [CrossRef]

49. Choi, D.; Kahn, H. Expedient syntheses of racemic 2,3-diaminopropanoic acid derivative. Tetrahedron Lett. 1995, 36, 7371-7374. [CrossRef]

50. Egbertson, M.S.; Homnick, C.F.; Hartman, G.D. A selective protection of 2,3-diaminopropionic acid. Synth. Commun. 1993, 23, 703-709. [CrossRef]

51. Englund, E.A.; Gopi, H.N.; Appella, D.H. An efficient synthesis of a probe for protein function: 2,3-diaminopropionic acid with orthogonal protecting groups. Org. Lett. 2004, 6, 213-215. [CrossRef]

52. Kumaraswamy, G.; Pitchaiah, A. Highly enantioselective synthesis of orthogonally protected (2S)-2,3diaminopropanoates through catalytic phase-transfer Aza-Henry reaction. Helv. Chim. Acta 2011, 94, 1543-1550. [CrossRef]

53. Cativiela, C.; Díaz-de-Villegas, M.D.; Gálvez, J.A. Diastereoselective strecker reaction of imines derived from D-glyceraldehyde. A new route to $\beta$-hydroxy- $\alpha$-amino acids. Tetrahedron Lett. 1995, 36, 2859-2860. [CrossRef]

54. Cativiela, C.; Diaz-de-Villegas, M.D.; Gálvez, J. Stereoselective Synthesis of $\alpha$-Hydroxy- $\beta$-amino Acids Using D-Glyceraldehyde as the Homochiral Source. Tetrahedron Asymmetry 1996, 7, 529-536. [CrossRef]

55. Mattson, R.J.; Pham, K.M.; Leuck, D.J.; Cowen, K.A. An improved method for reductive alkylation of amines using titanium (IV) isopropoxide and sodium cyanoborohydride. J. Org. Chem. 1990, 55, 2552-2554. [CrossRef] 
56. Zhao, M.M.; Li, J.; Mano, E.; Song, Z.J.; Tschaen, D.M.; Grabowski, E.J.J.; Reider, P.J. Oxidation of primary alcohols to carboxylic acids with sodium chlorite catalyzed by TEMPO and bleach. J. Org. Chem. 1999, 64, 2564-2566. [CrossRef]

57. Huang, L.; Teumelsan, N.; Huang, X. A facile method for oxidation of primary alcohols to carboxylic acids and its application in glycosaminoglycan syntheses. Chem. Eur. J. 2006, 12, 5246-5252. [CrossRef]

58. Siciliano, C.; Barattucci, A.; Bonaccorsi, P.; Di Gioia, M.L.; Leggio, A.; Minuti, L.; Romio, E.; Temperini, A. Synthesis of D-erythro-sphinganine through serine-derived $\alpha$-amino epoxides. J. Org. Chem. 2014, 79, 5320-5326. [CrossRef]

59. Borch, R.F.; Bernstein, M.D.; Dupont Durst, H. The cyanohydridoborate anion as a selective reducing agent. J. Am. Chem. Soc. 1971, 93, 2897-2904. [CrossRef]

60. Di Gioia, M.L.; Leggio, A.; Le Pera, A.; Liguori, A.; Siciliano, C. Highly selective conversion of aryl peptidyl ketones into the corresponding peptidyl alcohols. Eur. J. Org. Chem. 2004, 3, 463-467. [CrossRef]

61. Di Gioia, M.L.; Leggio, A.; Le Pera, A.; Liguori, A.; Pitrelli, A.F.; Siciliano, C. A convenient method for the stereoselective conversion of aryl peptidyl ketones into the corresponding aryl aminomethin derivatives, a novel class of modified peptides. Protein Pept. Lett. 2005, 12, 357-362. [CrossRef] [PubMed]

62. Di Gioia, M.L.; Leggio, A.; Liguori, A.; Perri, F.; Siciliano, C.; Viscomi, M.C. A preparation of N-Fmoc-N-methyl- $\alpha$-amino acids and N-Nosyl-N-methyl- $\alpha$-amino acids. Amino Acids 2010, 38, 133-143. [CrossRef] [PubMed]

63. Stewart, W.E.; Siddall, T.H. Nuclear magnetic resonance studies of amides. Chem. Rev. 1970, 70, 517-551. [CrossRef]

64. Marcovici-Mizrahi, D.; Gottlieb, H.E.; Marks, V.; Nudelman, A. On the stabilization of the syn-rotamer of amino acid carbamate derivatives by hydrogen bonding. J. Org. Chem. 1996, 61, 8402-8406. [CrossRef]

65. Modarresi-Alam, A.R.; Najaf, P.; Rostamizadeh, M.; Keykha, H.; Bijanzadeh, H.-R.; Kleinpeter, E. Dynamic ${ }^{1} \mathrm{H}-\mathrm{NMR}$ study of the barrier to rotationabout the $\mathrm{C}-\mathrm{N}$ bond in primary carbamates and its solvent dependence. J. Org. Chem. 2007, 72, 2208-2211. [CrossRef]

66. Deetz, M.J.; Forbes, C.C.; Jonas, M.; Malerich, J.P.; Smith, B.D.; Wiest, O. Unusually low barrier to carbamate C-N rotation. J. Org. Chem. 2002, 67, 3949-3952. [CrossRef]

67. Ernani, A.; Basso, E.A.; Pontes, R.M. Further studies on the rotational barriers of Carbamates. An NMR and DFT analysis of the solvent effect for cyclohexyl N,N-dimethylcarbamate. J. Mol. Struct. Theochem. 2002, 594, 199-206.

68. Solomon, M.E.; Lynch, C.L.; Rich, D.H. Synthesis of $N \alpha, N \beta$-alkylated diaminopropionic acid analogs. Tetrahedron Lett. 1995, 36, 4955-4958. [CrossRef]

69. Pitteloud, J.-P.; Bionda, N.; Cudi, P. Direct access to side chain $N, N^{\prime}$-diaminoalkylated derivatives of basic amino acids suitable for solid-phase peptide synthesis. Amino Acids 2013, 44, 321-333. [CrossRef]

70. Jurczak, J.; Golębiowski, A. Optically active N-protected $\alpha$-amino aldehydes in organic synthesis. Chem. Rev. 1989, 89, 149-164. [CrossRef]

71. Leggio, A.; Le Pera, A.; Liguori, A.; Napoli, A.; Romeo, C.; Siciliano, C.; Sindona, G. Highly stereoselective synthesis of optically pure C-aryl imines from $\alpha$-L-amino acid methyl esters. Synth. Commun. 2003, 33, 4331-4338. [CrossRef]

72. De Marco, R.; Di Gioia, M.L.; Liguori, A.; Perri, F.; Siciliano, C.; Spinella, M. N-alkylation of $\mathrm{N}$-arylsulfonyl- $\alpha$-amino acid methyl esters by trialkyloxonium tetrafluoroborates. Tetrahedron 2011, 67, 9708-9714. [CrossRef]

73. You, S.-L.; Kelly, J.W. Highly efficient enantiospecific synthesis of imidazoline-containing amino acids using bis (triphenyl) oxodiphosphonium trifluoromethanesulfonate. Org. Lett. 2004, 6, 1681-1684. [CrossRef] [PubMed]

74. Belsito, E.; Di Gioia, M.L.; Greco, A.; Leggio, A.; Liguori, A.; Perri, F.; Siciliano, C.; Viscomi, M.C. N-methyl-N-nosyl- $\beta^{3}$-amino acids. J. Org. Chem. 2007, 72, 4798-4802. [CrossRef] [PubMed]

75. Biron, E.; Chatterjee, J.; Kessler, H. Solid-phase synthesis of 1,3-azole-based peptides and peptidomimetics. Org. Lett. 2006, 8, 2417-2420. [CrossRef] [PubMed]

76. Anantharamaiah, G.M.; Sivanandaiah, K.M. Transfer hydrogenation; a convenient method for removal of some commonly used protecting groups in peptide synthesis. J. Chem. Soc. Perkin Trans. 1977, 1, 490-491. [CrossRef] 
77. Felix, A.M.; Heimer, E.P.; Lambros, T.J.; Tzougraki, C.; Meienhofer, J. Rapid removal of protecting groups from peptides by catalytic transfer hydrogenation with 1,4-cyclohexadiene. J. Org. Chem. 1978, 43, 4194-4196. [CrossRef]

78. Siciliano, C.; De Marco, R.; Guidi, L.E.; Spinella, M.; Liguori, A. A one-pot procedure for the preparation of N-9-fluorenylmethyloxycarbonyl- $\alpha$-amino diazoketones from $\alpha$-amino acids. J. Org. Chem. 2012, 77, 10575-10582. [CrossRef]

79. Aiello, D.; Furia, E.; Siciliano, C.; Bongiorno, D.; Napoli, A. Study of the coordination of ortho-tyrosine and trans-4-hydroxyproline with aluminum(III) and iron(III). J. Mol. Liq. 2018, 269, 387-397. [CrossRef]

80. De Marco, R.; Di Gioia, M.L.; Leggio, A.; Liguori, A.; Perri, F.; Siciliano, C.; Viscomi, M.C. A new non-natural arginine-like amino acid derivative with a sulfamoyl group in the side-chain. Amino Acids 2010, 38, 691-700. [CrossRef]

81. Piazzolla, F.; Siciliano, C.; Minuti, L.; Temperini, A. Exploration of Synthetic strategies for the stereoselective preparation of novel tetrahydrofuran-containing biaryls: A high-pressure promoted Diels-Alder approach. Tetrahedron 2018, 74, 6534-6543. [CrossRef]

82. Di Donna, L.; Benabdelkamel, H.; Taverna, D.; Indelicato, S.; Aiello, D.; Napoli, A.; Sindona, G.; Mazzotti, F. Determination of ketosteroid hormones in meat by liquid chromatography tandem mass spectrometry and derivatization chemistry. Anal. Chem. Biochem. 2015, 407, 5835-5842. [CrossRef] [PubMed]

83. Di Donna, L.; Mazzotti, F.; Napoli, A.; Salerno, R.; Saijad, A.; Sindona, G. Secondary metabolism of olive secoiridoids. New microcomponents detected in drupes by electrospray ionization and high-resolution tandem mass spectrometry. Rapid Commun. Mass Spectrom. 2007, 21, 273-278. [CrossRef] [PubMed]

84. Aiello, D.; Giambona, A.; Leto, F.; Passarello, C.; Damiani, G.; Maggio, A.; Siciliano, C.; Napoli, A. Human coelomic fluid investigation: A MS approach to prenatal screening. Sci. Rep. 2018, 8, 10973. [CrossRef] [PubMed]

85. Antoniou, A.I.; Pepe, D.A.; Aiello, D.; Siciliano, C.; Athanassopoulos, C.M. Chemoselective protection of glutathione in the preparation of bioconjugates: The case of tripanothione disulfide. J. Org. Chem. 2016, 81, 4353-4358. [CrossRef] [PubMed]

Sample Availability: Samples of compounds are not available from the authors.

(C) 2020 by the authors. Licensee MDPI, Basel, Switzerland. This article is an open access article distributed under the terms and conditions of the Creative Commons Attribution (CC BY) license (http://creativecommons.org/licenses/by/4.0/). 